\title{
Isocyanic acid in a global chemistry transport model: Tropospheric distribution, budget, and identification of regions with potential health impacts
}

\author{
Paul. J. Young, ${ }^{1,2}$ Louisa K. Emmons, ${ }^{3}$ James M. Roberts, ${ }^{2}$ Jean-François Lamarque, ${ }^{3}$ \\ Christine Wiedinmyer, ${ }^{3}$ Patrick Veres, ${ }^{2,4,5}$ and Trevor C. VandenBoer ${ }^{6}$
}

Received 22 December 2011; revised 10 April 2012; accepted 22 April 2012; published 31 May 2012.

[1] This study uses a global chemical transport model to estimate the distribution of isocyanic acid (HNCO). HNCO is toxic, and concentrations exceeding 1 ppbv have been suggested to have negative health effects. Based on fire studies, HNCO emissions were scaled to those of hydrogen cyanide (30\%), resulting in yearly total emissions of $1.5 \mathrm{Tg}$ for 2008, from both anthropogenic and biomass burning sources. Loss processes included heterogeneous uptake ( $\mathrm{pH}$ dependent), dry deposition (like formic acid), and reaction with the $\mathrm{OH}$ radical $\left(\mathrm{k}=1 \times 10^{-15}\right.$ molecule $\left.\mathrm{cm}^{-1} \mathrm{~cm}^{-1}\right)$. Annual mean surface $\mathrm{HNCO}$ concentrations were highest over parts of China (maximum of $470 \mathrm{pptv}$ ), but episodic fire emissions gave much higher levels, exceeding 4 ppbv in tropical Africa and the Amazon, and exceeding $10 \mathrm{ppbv}$ in Southeast Asia and Siberia. This suggests that large biomass burning events could result in deleterious health effects for populations in these regions. For the tropospheric budget, using the model-calculated $\mathrm{pH}$ the HNCO lifetime was 37 days, with the split between dry deposition and heterogeneous loss being 95\%:5\%. Fixing the heterogeneous loss rate at $\mathrm{pH}=7$ meant that this process dominated, accounting for $\sim 70 \%$ of the total loss, giving a lifetime of 6 days, and resulting in upper tropospheric concentrations that were essentially zero. However, changing the $\mathrm{pH}$ does not notably impact the high concentrations found in biomass burning regions. More observational data is needed to evaluate the model, as well as a better representation of the likely underestimated biofuel emissions, which could mean more populations exposed to elevated HNCO concentrations.

Citation: Young, P. J., L. K. Emmons, J. M. Roberts, J.-F. Lamarque, C. Wiedinmyer, P. Veres, and T. C. VandenBoer (2012), Isocyanic acid in a global chemistry transport model: Tropospheric distribution, budget, and identification of regions with potential health impacts, J. Geophys. Res., 117, D10308, doi:10.1029/2011JD017393.

\section{Introduction}

[2] Isocyanic acid (HNCO) is a volatile, moderately acidic compound, and the simplest member of the isocyanate family. $\mathrm{HNCO}$ is toxic, and in vivo carbamylation reactions of proteins with its aqueous anion (cyanate, $\mathrm{NCO}^{-}$) have

\footnotetext{
${ }^{1}$ Cooperative Institute for Research in the Environmental Sciences, University of Colorado Boulder, Boulder, Colorado, USA.

${ }^{2}$ Chemical Sciences Division, Earth System Research Laboratory, NOAA, Boulder, Colorado, USA.

${ }^{3}$ National Center for Atmospheric Research, Boulder, Colorado, USA.

${ }^{4}$ Department of Chemistry and Biochemistry, University of Colorado Boulder, Boulder, Colorado, USA.

${ }^{5}$ Now at Max Planck Institute for Chemistry, Mainz, Germany.

${ }^{6}$ Department of Chemistry, University of Toronto, Toronto, Ontario, Canada.

Corresponding author: P. J. Young, Chemical Sciences Division, Earth System Research Laboratory, NOAA, Boulder, CO 80305, USA. (paul.j.young@noaa.gov)

Copyright 2012 by the American Geophysical Union. 0148-0227/12/2011JD017393
}

been implicated as the cause of several negative health effects [Wang et al., 2007]. Based on the physical properties of HNCO, Roberts et al. [2011] estimated that atmospheric HNCO concentrations exceeding 1 ppbv could lead to protein-damaging chemistry. The goal of this study is to use the chemistry transport model MOZART-4 (Model for Ozone and Related chemical Tracers-4) [Emmons et al., 2010] to estimate the first global distribution of HNCO and identify areas, and their environmental conditions, where elevated $\mathrm{HNCO}$ concentrations might exist.

[3] Controlled laboratory studies have shown that HNCO is a component of biomass burning emissions [Veres et al., 2010], with an emissions profile closely correlated with that of hydrogen cyanide (HCN), as both are formed from protein pyrolysis. HNCO is also emitted from low-temperature combustion of coal [Nelson et al., 1996], and is a product from the photochemistry of some amine and amide compounds [Schade and Crutzen, 1995; Barnes et al., 2010]. In addition, $\mathrm{HNCO}$ is present in exhaust of diesel vehicles using urea-selective catalytic reduction (SCR) technology, at least 
in model systems [Kröcher et al., 2005; Heeb et al., 2011]. It is important to understand this source better since the number of SCR vehicles is expected to grow in the European Union and USA, following regulations aimed at reducing $\mathrm{NO}_{\mathrm{x}}$ emissions [Heeb et al., 2011]. Furthermore, the biomass burning source of $\mathrm{HNCO}$ would also likely change in the future, concomitant with any changes in the occurrence of fires [e.g., Bowman et al., 2009].

[4] Measurements of $\mathrm{HNCO}$ at atmospheric levels have only recently been made possible by the advent of a new mass spectrometry technique [Veres et al., 2008; Roberts et al., 2010]. Using this method, HNCO was identified at levels of up to $200 \mathrm{pptv}$ in ambient air during the 2010 Fourmile Canyon fire in Boulder, Colorado, and up to 100 pptv in urban Los Angeles, California [Roberts et al., 2011], with the temporal profile of the latter measurements suggesting a partial photochemical source. The same study suggested "background" concentrations of around $10 \mathrm{pptv}$ in ambient air during the summer season.

[5] In the troposphere, the major loss process for $\mathrm{HNCO}$ is likely to be through dry deposition and heterogeneous uptake to liquid water and aerosols, with subsequent aqueous-phase reactions making this an irreversible process [Roberts et al., 2011]. Due to the acidic nature of HNCO $\left(\mathrm{pK}_{\mathrm{a}}=3.7\right.$, the same as formic acid; mildly acidic) [Belson and Strachan, 1982], its gas-water partitioning is highly $\mathrm{pH}$ dependent, with the effective Henry's Law coefficient increasing from $25 \mathrm{M} \mathrm{atm}^{-1}$ at $\mathrm{pH}=3$ to $42000 \mathrm{M} \mathrm{atm}^{-1}$ at $\mathrm{pH}=7$ (using data from Roberts et al. [2011]). Thus, one of the challenges of understanding any global distribution and budget of $\mathrm{HNCO}$ is modeling $\mathrm{pH}$ correctly.

[6] Chemical reaction data for HNCO relevant to atmospheric conditions are somewhat limited. Extrapolating the combustion kinetic data of Tsang [1992] to atmospheric temperatures suggests a rate coefficient for the reaction of HNCO with OH on the order of $10^{-15} \mathrm{~cm}^{3}$ molecule $\mathrm{s}^{-1} \mathrm{~s}^{-1}$, resulting in a lifetime of over 30 years with this reaction for an $\mathrm{OH}$ concentration of $10^{6}$ molecules $\mathrm{cm}^{-3}$. In terms of photolysis, there are limited spectroscopic data [Dixon and Kirby, 1968; Brown et al., 1996; Brownsword et al., 1996; Berghout et al., 1998], with very little information in the actinic region. Extrapolation of the Dixon and Kirby [1968] data to the actinic region suggests that $\mathrm{HNCO}$ is likely very stable to photochemical loss in the troposphere and lower stratosphere (lifetime of months to years). Overall, uncertainty in the contribution of this process to the HNCO budget will only be reduced by measuring cross sections at tropospherically relevant wavelengths.

[7] The goal of this study is to use a chemical transport model to provide constraints on the processes that are the most important in determining HNCO concentrations. Due to the current paucity of information concerning $\mathrm{HNCO}$, it is not expected that a model will give highly accurate $\mathrm{HNCO}$ concentrations; rather, this study is aimed at identifying particular sets of circumstances (e.g., emissions, environmental $\mathrm{pH}$ ) that result in elevated HNCO levels, which could be of concern and worthy of further investigation. In addition, the study examines the geographical patterns of high HNCO concentrations.

[8] This paper is organized as follows. Section 2 details the modifications to the standard MOZART-4 model in order to accommodate $\mathrm{HNCO}$, including emissions, chemistry, and heterogeneous and depositional loss. The different MOZART-4 simulations conducted are described in Section 3. The tropospheric budget and distribution of $\mathrm{HNCO}$ are presented in Section 4, including a comparison against the limited observational data. Section 5 presents an analysis of where and when $\mathrm{HNCO}$ concentrations exceed $1 \mathrm{ppbv}$. A discussion of the results follows in Section 6, and a summary and concluding remarks in Section 7.

\section{MOZART-4, the Inclusion of HNCO, and Modeled pH}

[9] The base MOZART-4 model applied for this study was the same as that described by Emmons et al. [2010], except configured for participation in the Arctic Research of the Composition of the Troposphere from Aircraft and Satellites (ARCTAS) experiment, as described by Wespes et al. [2012]. This configuration includes the addition of hydrogen cyanide (HCN) [Randel et al., 2010], the use of meteorological fields from GEOS-5 (Goddard Earth Observing System Data Assimilation System Version 5) assimilation products (http://gmao.gsfc.nasa.gov/products), and the ARCTAS emissions data set as compiled by D. G. Streets and Q. Zhang at Argonne National Laboratory (see http://www.cgrer.uiowa.edu/arctas/emission.html) [Zhang et al., 2009]. The simulation year was 2008.

\subsection{HNCO Emissions}

[10] Biomass burning emissions of HNCO were determined by simply scaling the HCN emissions by a factor of 0.3 , which is the lower end of the range of $\mathrm{HNCO} / \mathrm{HCN}$ ratios obtained from measuring biomass burning emissions of many fuels (0.3-0.5) [Burling et al., 2010; Roberts et al., 2011]. Daily varying biomass burning emissions of HCN were calculated using the FINN (Fire Inventory from NCAR) model, version 1.0 [Wiedinmyer et al., 2011], appropriate for the year 2008. Biomass burning emissions were emitted directly at the surface, ignoring any vertical redistribution due to pyro-convective lifting [e.g., Fromm et al., 2005], which could be important as HNCO is chiefly emitted during the flaming stage [Veres et al., 2010]. Pfister et al. [2005] reported that using vertical redistribution versus surface emissions of $\mathrm{CO}$ in MOZART did not significantly alter their results, although a large proportion of $\mathrm{CO}$ comes from the smoldering stage of fires [e.g., Crutzen and Andreae, 1990].

[11] Anthropogenic $\mathrm{HNCO}$ emissions were determined by scaling $\mathrm{HCN}$ emissions, also by a factor of 0.3 . In turn, the $\mathrm{HCN}$ emissions were derived by scaling the anthropogenic component of $\mathrm{CO}$ emissions by a factor of 0.003 . This latter scaling was derived from a $\mathrm{HCN} / \mathrm{CO}$ ratio of 0.006 followed by an additional scaling by 0.5 to account for the fact that not all anthropogenic $\mathrm{CO}$ emissions are necessarily coemitted with HCN (or HNCO). Furthermore, the resulting $\mathrm{HNCO} / \mathrm{CO}$ ratio of $0.9 \mathrm{mmol} / \mathrm{mol}$ is within the range reported for flaming stage fires by Veres et al. [2010] (0.25$1.2 \mathrm{mmol} / \mathrm{mol}$ ), which is relevant as the chief anthropogenic source of HNCO (and HCN) is likely biofuel combustion. However, as stated in the introduction, observations reported by Roberts et al. [2011] do suggest an additional secondary photochemical source of HNCO, not directly accounted for in this study. 
(a) Biomass burning: $661 \mathrm{Gg} \mathrm{yr}^{-1}$

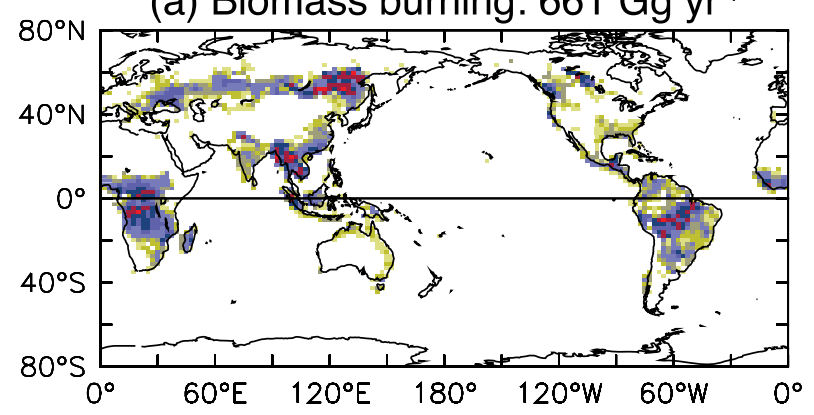

(b) Anthropogenic: $828 \mathrm{Gg} \mathrm{yr}^{-1}$

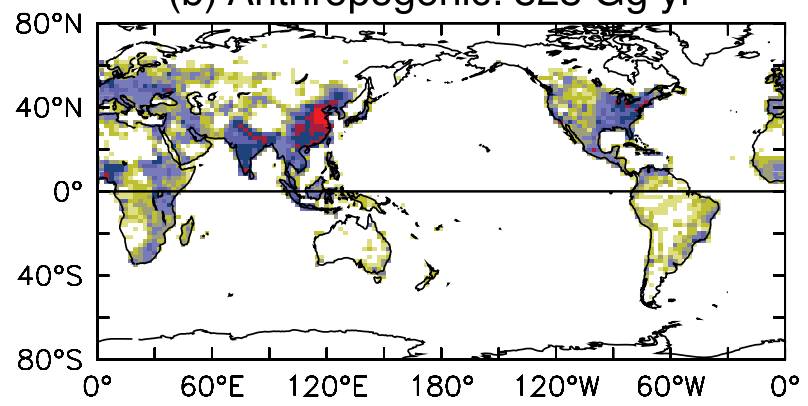

(c) Total: $1490 \mathrm{Gg} \mathrm{yr}^{-1}$

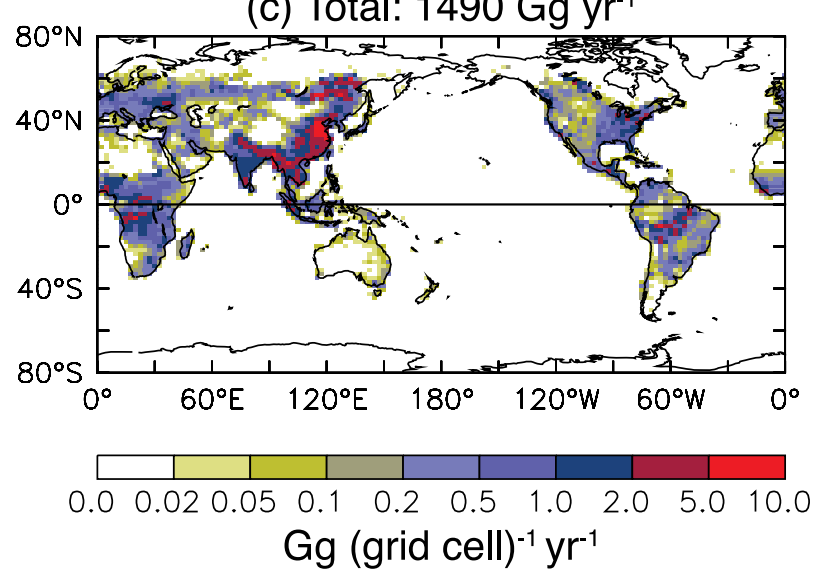

Figure 1. Emissions of $\mathrm{HNCO}$ in $\mathrm{Gg} \mathrm{HNCO}$ per grid cell per year. The emissions are shown for (a) the biomass burning component, (b) the anthropogenic component, and (c) the total of Figures $1 \mathrm{a}$ and $1 \mathrm{~b}$. The anthropogenic emissions in Figure $1 \mathrm{~b}$ are doubled for the $2 \times$ Anthro simulation. Note the nonlinear color scale.

[12] Figure 1 shows the distribution of the HNCO emissions, which total $1490 \mathrm{Gg} \mathrm{a}^{-1}$ with a near even split between biomass burning (44\%) and anthropogenic (56\%) sources. Overall, while the "parent" HCN emissions result in a good comparison with satellite and ground-based HCN observations (D. Kinnison, personal communication, 2011), it is clear that the HNCO emissions are a large source of uncertainty in this study. However, by using the lower bound of the $\mathrm{HNCO} / \mathrm{HCN}$ ratio, these emissions err on the conservative side.

\subsection{HNCO Loss Processes}

[13] Reaction of $\mathrm{HNCO}$ with $\mathrm{OH}$ was included with a rate coefficient of $10^{-15} \mathrm{~cm}^{3}$ molecule ${ }^{-1} \mathrm{~s}^{-1}$ [Tsang, 1992], excluding any temperature dependence. As suggested in the introduction, HNCO photolysis was omitted due to both the absence of cross-section measurements and the likely high stability of the molecule at tropospherically relevant wavelengths. This will likely mean that calculated HNCO concentrations are overestimated in and above the upper troposphere.

[14] Dry deposition of HNCO was included using the same velocities as for formaldehyde (also used as a surrogate species for formic and acetic acids). For a mixed layer depth of $1 \mathrm{~km}$, this results in an annual average HNCO lifetime against dry deposition of 1-3 days over the ocean and 12 weeks over vegetation. For the ocean, this lifetime is of the same order as that for nitric acid, which would seem justifiable considering that the ocean is slightly alkaline, resulting in an $\mathrm{HNCO}$ solubility close to that of nitric acid $\left(\sim 10^{5} \mathrm{M} \mathrm{atm}^{-1}\right)$.

[15] The loss of HNCO through heterogeneous uptake was included as a function of $\mathrm{pH}$ and liquid water content. Gasliquid partitioning was calculated with an effective Henry's Coefficient $H_{\text {eff }}$, expressed as

$$
H_{e f f}=H^{*}\left(1+K_{a} /\left[\mathrm{H}^{+}\right]\right)
$$

where $\mathrm{H}^{*}$ is the intrinsic Henry's Coefficient $\left(21 \mathrm{M} \mathrm{atm}^{-1}\right)$ and $K_{a}$ is the equilibrium constant for dissociation $\left(2 \times 10^{-4} \mathrm{M}\right.$; from $\left.\mathrm{pK}_{\mathrm{a}}=3.7\right)$, using data from Roberts et al. [2011]. The effect of acidity $\left(\left[\mathrm{H}^{+}\right]\right)$is discussed below. Partitioning between the gas and aqueous phases is calculated using the equilibrium fractionation $f$ (the dimensionless ratio of the aqueous to gas concentrations), expressed as

$$
f=H_{\text {eff }} R T L
$$

where $R$ is the gas constant (atm $\mathrm{K}^{-1} \mathrm{~mol}^{-1}$ ), $T$ is temperature, and $L$ is cloud liquid water content as a volume fraction (L water $(\mathrm{L} \text { air })^{-1}$ ) [Jacob, 2000]. In the model, aqueous loss of HNCO occurs only when $L$ is greater than or equal to $10 \mathrm{ppbv}$, and then the loss is assumed to be irreversible. There is no consideration of aqueous-phase reactions of HNCO [Roberts et al., 2011], so this results in an upper limit to the loss rate for this process (i.e., there is no $\mathrm{HNCO}$ coming back out of solution in the model).

[16] MOZART-4 calculates $\mathrm{pH}$ by solving an electroneutrality equation,

$$
\begin{aligned}
{\left[\mathrm{H}^{+}\right]+\left[\mathrm{NH}_{4}^{+}\right]=} & {\left[\mathrm{OH}^{-}\right]+\left[\mathrm{HCO}_{3}^{-}\right]+\left[\mathrm{NO}_{3}^{-}\right]+\left[\mathrm{HSO}_{3}^{-}\right] } \\
& +\left[\mathrm{SO}_{3}^{2-}\right]+\left[\mathrm{SO}_{4}^{2-}\right]
\end{aligned}
$$

using a bisection method to converge on a value of $\left[\mathrm{H}^{+}\right]$. This method only considers dissolved carbon dioxide $\left(\mathrm{CO}_{2}\right)$, sulfur dioxide $\left(\mathrm{SO}_{2}\right)$, nitric acid $\left(\mathrm{HNO}_{3}\right)$ and ammonia $\left(\mathrm{NH}_{3}\right)$, along with water, as the determinants of cloud water $\mathrm{pH}$, omitting the alkaline influence of soil dust (via $\mathrm{Ca}^{2+}$ ) [e.g., Rodhe et al., 2002] and acidic influence of dissolved organic acids, such as formic and acetic acid [e.g., Keene and Galloway, 1988].

[17] Figure 2 shows the global distribution of the annual mean, cloud liquid water-weighted $\mathrm{pH}$ ("LWC-pH"), from MOZART-4. This was determined as tropospheric column averages of the model-calculated $\mathrm{pH}$, weighting the $\mathrm{pH}$ value at a given pressure level by the mass of cloud liquid 


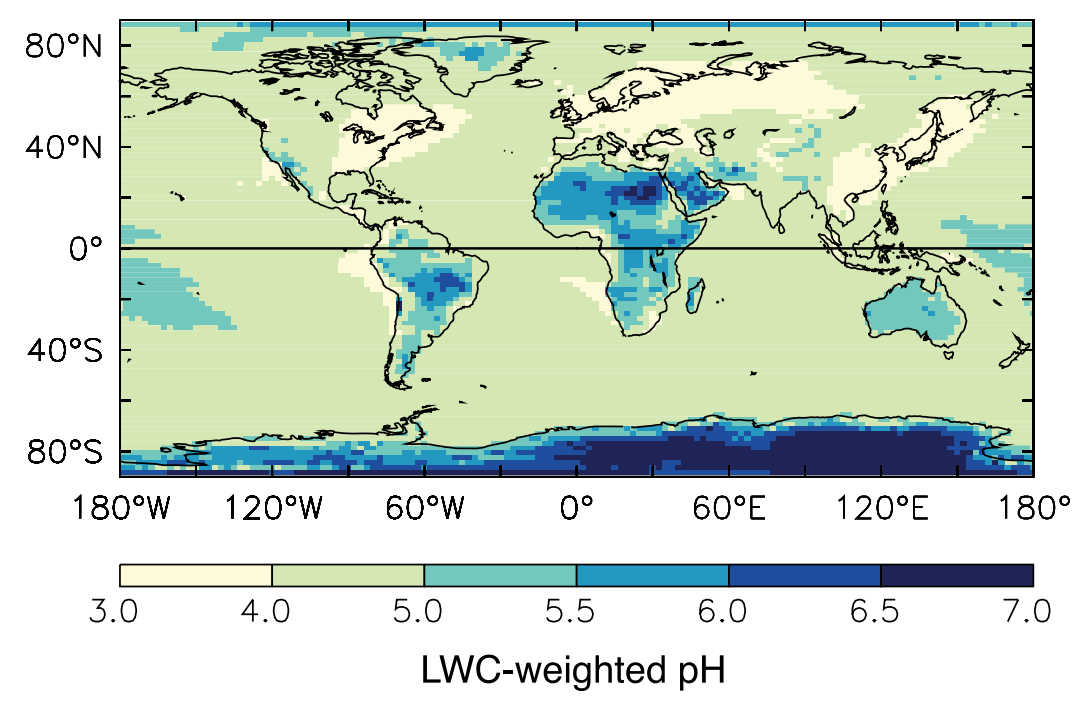

Figure 2. Annual mean, cloud liquid water content-weighted $\mathrm{pH}$ values from the $\mathrm{pH}$ calc simulation (see Table 1). Weighted pHs calculated for the tropospheric column (where ozone $\leq 150$ ppbv).

water, delimiting the troposphere using the 150 ppbv ozone contour [Stevenson et al., 2006] (as in Section 4.1). Although not exactly the $\mathrm{pH}$ of precipitation (which is not calculated by MOZART-4), the LWC-pH calculation does provide data to compare with the global precipitation $\mathrm{pH}$ model study of Rodhe et al. [2002]. The area-weighted, global mean $\mathrm{pH}$ value is 4.6.

[18] In general, the geographical variation of LWC-pH correlates with that reported by Rodhe et al. [2002], with low $\mathrm{pH}$ (high acidity; $\mathrm{pH}=3-4$ ) apparent over the eastern USA, Europe, and east Asia. As in their study, the low $\mathrm{pH}$ in these regions is likely due to the acidifying impact of large anthropogenic sulfate emissions. Figure 2 shows that higher $\mathrm{pH}$ (less acidity; $\mathrm{pH}>5.5$ ) dominates most of Africa, the Middle East, parts of South America, and the Antarctic, also in agreement with Rodhe et al. [2002]. However, in general the LWC-weighted $\mathrm{pH}$ is more acidic than Rodhe et al. [2002], and their results were already more acidic than the (limited) observations suggest. For MOZART-4, the lack of an alkaline influence of (e.g.) soil dust means that the modelcalculated $\mathrm{pH}$ is likely too acidic.

\section{Simulations}

[19] Table 1 shows the names of the simulations together with a brief description. The role of acidity is the main sensitivity explored in these simulations, due both to the near exponential nature of the increase of heterogeneous loss rate with increasing $\mathrm{pH}$, and the difficulty of simulating $\mathrm{pH}$ values in a global model. Hence, in addition to the control simulation where $\mathrm{pH}$ was calculated online (the $\mathrm{pH}$ calc simulation), six further model simulations were completed, where the heterogeneous loss rate of $\mathrm{HNCO}$ was fixed at $\mathrm{pH}$ values increasing in integers from $\mathrm{pH} 2$ (low Henry's Law coefficient) to $\mathrm{pH} 7$ (high Henry's Law coefficient) at all locations. Globally, most cloud water $\mathrm{pHs}$ are in the range 3-6, although a $\mathrm{pH}$ range of 2-7 encompasses the broad spectrum of observed acidity [Li and Aneja, 1992, and references therein].
[20] A further simulation was conducted where the anthropogenic component of HNCO emissions was doubled (to be $1656 \mathrm{Gg} \mathrm{a}^{-1}$; see Figure 1), as the standard emissions may be underestimated for regions where biofuels are widely used. (Conversely, the emissions may be overestimated where the chief source is from fossil fuel burning, such as the eastern USA.)

[21] Each simulation was run for two years, with only the second year analyzed.

\section{The Tropospheric Budget of HNCO and Its Global Distribution}

[22] This section presents the distribution of modeled HNCO surface and zonal mean concentrations, as well as its tropospheric budget. The main goal is to compare the " $\mathrm{pH}$ " simulations and assess the sensitivity of individual budget terms and $\mathrm{HNCO}$ abundances to $\mathrm{pH}$. Section 4.2 also shows a limited observation-model comparison.

\subsection{Tropospheric Budget}

[23] Figure 3 summarizes the yearly, global tropospheric budget terms for $\mathrm{HNCO}$ for the $\mathrm{pH} 2-\mathrm{pH} 7$ and $\mathrm{pH}$ _calc simulations, showing the average burden for the year (Figure 3a), the monthly mean loss fluxes via wet (heterogeneous loss)

Table 1. List of Model Simulations and a Brief Description

\begin{tabular}{|c|c|}
\hline Simulation & Description \\
\hline pH_calc & $\begin{array}{l}\text { Control simulation. } H_{e f f} \text { for } \mathrm{HNCO} \\
\text { determined from model-calculated } \mathrm{pH} \text {. }\end{array}$ \\
\hline $\mathrm{pH} 2$ & $\begin{array}{l}H_{\text {eff }} \text { for } \mathrm{HNCO} \text { calculated as if the } \mathrm{pH} \text { is } \\
2 \text { everywhere. }\end{array}$ \\
\hline $\mathrm{pH} 3$ & As $\mathrm{pH} 2$, but $H_{\text {eff }}$ calculated for $\mathrm{pH} 3$. \\
\hline $\mathrm{pH} 4$ & As $\mathrm{pH} 2$, but $H_{\text {eff }}$ calculated for $\mathrm{pH} 4$. \\
\hline $\mathrm{pH} 5$ & As $\mathrm{pH} 2$, but $H_{\text {eff }}$ calculated for $\mathrm{pH} 5$. \\
\hline $\mathrm{pH} 6$ & As $\mathrm{pH} 2$, but $H_{\text {eff }}$ calculated for $\mathrm{pH} 6$. \\
\hline $\mathrm{pH} 7$ & As $\mathrm{pH} 2$, but $H_{\text {eff }}$ calculated for $\mathrm{pH} 7$. \\
\hline $2 \times$ Anthro & $\begin{array}{l}\text { As pH_calc, but with doubled } \\
\text { anthropogenic HNCO emissions. }\end{array}$ \\
\hline
\end{tabular}


(a) HNCO burden (avg)

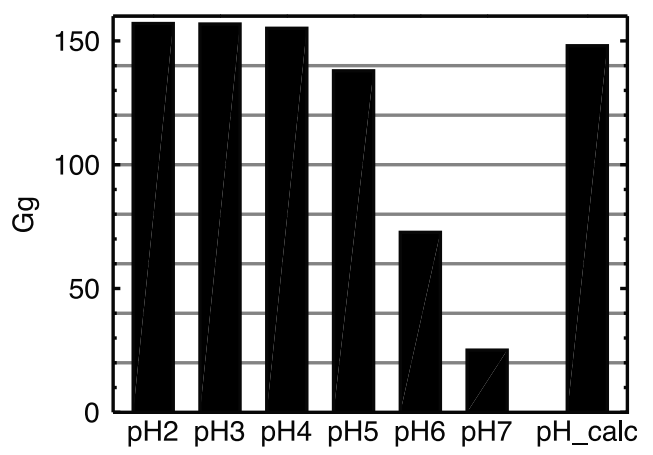

(b) HNCO loss rates (avg)

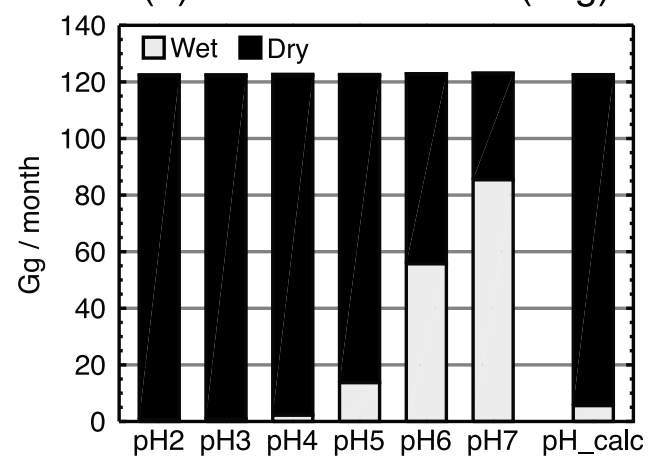

(c) HNCO lifetime

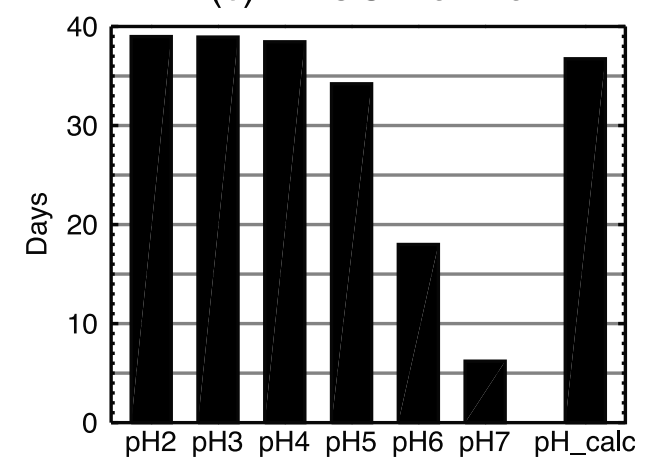

Figure 3. Tropospheric budget statistics for HNCO for the pH2-pH7 and pH_calc simulations, showing (a) the average tropospheric burden (Gg HNCO), (b) the monthly mean loss fluxes via wet (heterogeneous; light) and dry (black) deposition (Gg HNCO per month; each month weighted evenly), and (c) the tropospheric HNCO lifetime (days).

and dry deposition (Figure 3b), and the lifetime, calculated from the average burden divided by the annual total loss (i.e., a "turnover flux") (Figure 3c). All terms were calculated using monthly means, and with the troposphere defined where the ozone concentration was less than or equal to 150 ppbv (as per Stevenson et al. [2006]). Gas-phase loss of $\mathrm{HNCO}$ was very small in all the simulations (ranging from $0.07 \%$ to $0.4 \%$ of the total loss) and is therefore not indicated in Figure 3b, although it was included in the calculation of the lifetime. Note that the loss rates in Figure $3 \mathrm{~b}$ are close to the emission rate, indicating that $\mathrm{HNCO}$ is in approximate steady state.
[24] Figure 3 indicates the importance of $\mathrm{pH}$ in determining the losses and lifetime of HNCO. Figure $3 \mathrm{~b}$ shows that the $\mathrm{pH} 2, \mathrm{pH} 3, \mathrm{pH} 4$ and $\mathrm{pH} \_$calc simulations have similarly low values of heterogeneous $\mathrm{HNCO}$ loss, ranging from $0.6 \%$ $(\mathrm{pH} 2)$ to $4.5 \%$ ( $\mathrm{pH}$ _calc) of the total loss, resulting in similar HNCO lifetimes and burdens for these simulations. The low $H_{\text {eff }}$ values for these low $\mathrm{pHs}$ result in a tropospheric $\mathrm{HNCO}$ lifetime of over a month, with the loss dominated by (relatively slow) dry deposition. The budget statistics for the $\mathrm{pH}$ _calc simulation are between those for the $\mathrm{pH} 4$ and $\mathrm{pH} 5$ simulations, consistent with the global average $\mathrm{pH}$ value of 4.6 (Section 2.2).

[25] Moving from the $\mathrm{pH} 5$ to $\mathrm{pH} 6$ to $\mathrm{pH} 7$ simulations, the fraction of the total loss via heterogeneous processes increases markedly, from $11.2 \%$ to $45.4 \%$ to $69.5 \%$, respectively. The large jumps in the fraction result from the order of magnitude increases in $H_{\text {eff }}$ between each successive $\mathrm{pH}$, as compared to the far smaller $H_{\text {eff }}$ changes between the low $\mathrm{pH}$ simulations. The increase in the importance of the faster heterogeneous loss is reflected in the concomitant decrease in the burden and lifetime of $\mathrm{HNCO}$ for these simulations, culminating in a tropospheric burden and lifetime for the $\mathrm{pH} 7$ simulation that are a factor of $\sim 6$ less than for the $\mathrm{pH} 2$ simulation.

[26] Budget statistics for the $2 \times$ Anthro simulation are not shown in Figure 3, but they generally scale linearly from the $\mathrm{pH}$ _calc simulation. Compared to $\mathrm{pH}$ _calc, the 55\% increase in $\overline{\mathrm{HNCO}}$ emissions in $2 \times$ Anthro results in a $53 \%$ increase in the HNCO burden, and a $55 \%$ increase in the total loss rate, altogether resulting in a very similar tropospheric lifetime $(1.7 \%$ shorter with $2 \times$ Anthro). The fraction of the total loss accounted for by heterogeneous processes is $4.4 \%$, also very similar to $\mathrm{pH}$ _calc.

\subsection{Global Distribution}

[27] Figure 4 shows the annual mean surface (lowest model level) $\mathrm{HNCO}$ concentration for the $\mathrm{pH}$ _calc simulation, together with the differences between the $\mathrm{pH}$-calc (Figure 4a) and $2 \times$ Anthro (Figure 4b), pH6 (Figure 4c), and pH7 (Figure 4d) simulations. Figure 5 is the same as Figure 4, except for the yearly averaged zonal mean concentration. As suggested in the previous section, these simulations show the greatest differences from each other; the $\mathrm{pH} 2-\mathrm{pH} 5$ simulations are quite similar to $\mathrm{pH}$-calc and therefore are not shown here. The impacts of doubling anthropogenic emissions and environmental $\mathrm{pH}$ are discussed in Sections 4.2.1 and 4.2.2 respectively.

[28] Figure 4a shows that annual mean HNCO concentrations in excess of 100 pptv are present in the high anthropogenic emitting regions of northern India (the IndoGangetic Plain), Southeast (SE) Asia, China, and eastern USA (see Figure 1b). Similarly high annual mean HNCO concentrations are also present in regions influenced by large biomass burning emissions (see Figure 1), including tropical Africa, Siberia, and the Amazon. Biomass burning emissions are also important for SE Asia, where they are combined with large anthropogenic emissions.

[29] China contains the highest annual mean surface HNCO concentrations at 470 pptv. This mostly reflects the sustained high anthropogenic emissions (which have no seasonal cycle in the model), and other regions are seen to have higher $\mathrm{HNCO}$ concentrations for any given day, or 
(a) $\mathrm{pH} \_$calc

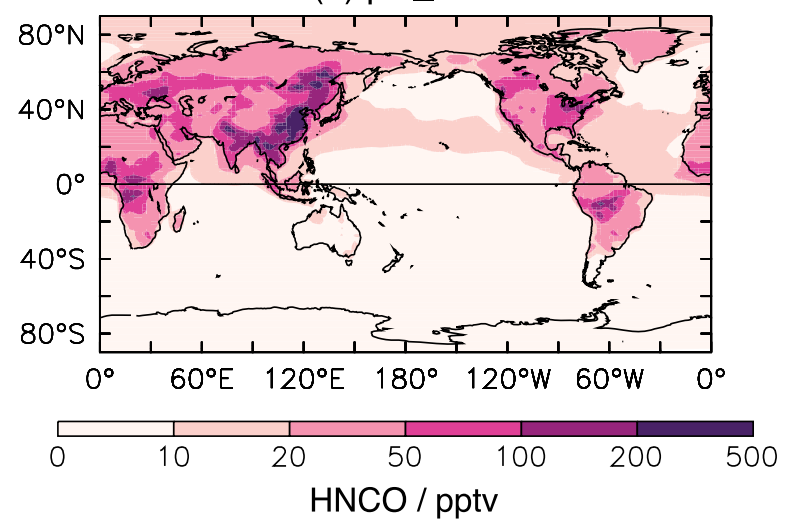

(b) 2xAnthro - pH_calc

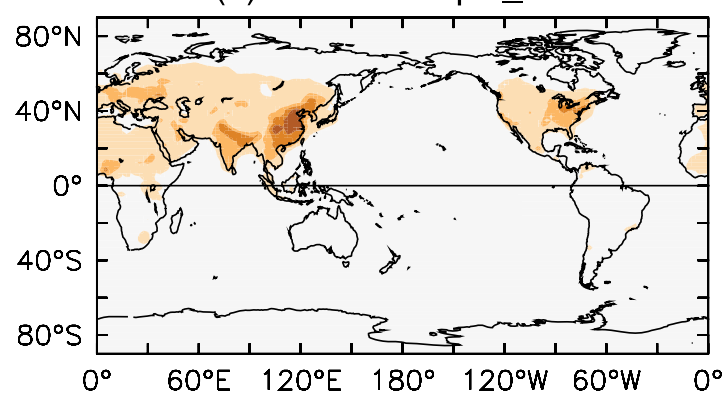

(c) $\mathrm{pH} 6-\mathrm{pH} \_$calc

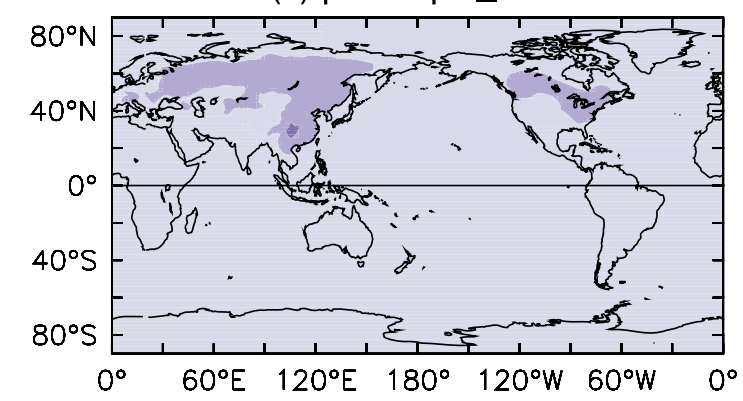

(d) $\mathrm{pH} 7-\mathrm{pH} \_$calc

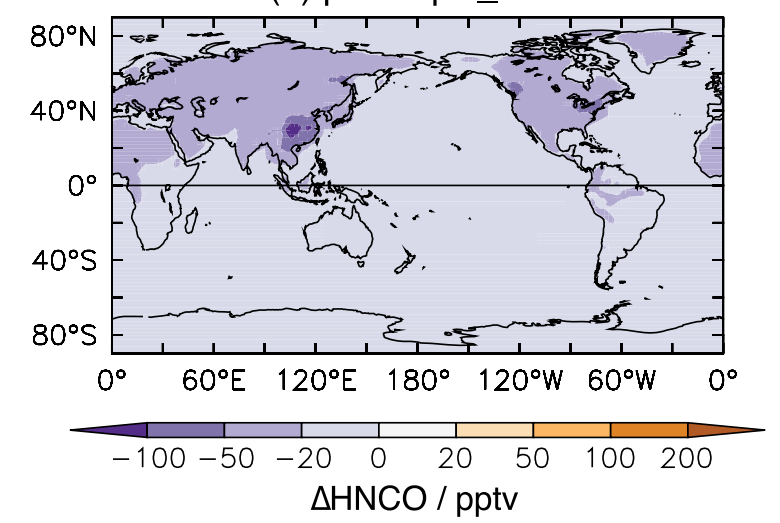

Figure 4. (a) Annual mean surface (lowest model level) HNCO concentrations for the $\mathrm{pH}$-calc simulation. Also shown are the differences in annual mean surface $\mathrm{HNCO}$ concentration between $\mathrm{pH}$ calc and (b) the $2 \times$ Anthro simulation, (c) the $\mathrm{pH} 6$ simulation, and (d) the $\mathrm{pH} 7$ simulation. Concentrations and differences are expressed in pptv; note the nonlinear color scale. (a) pH_calc

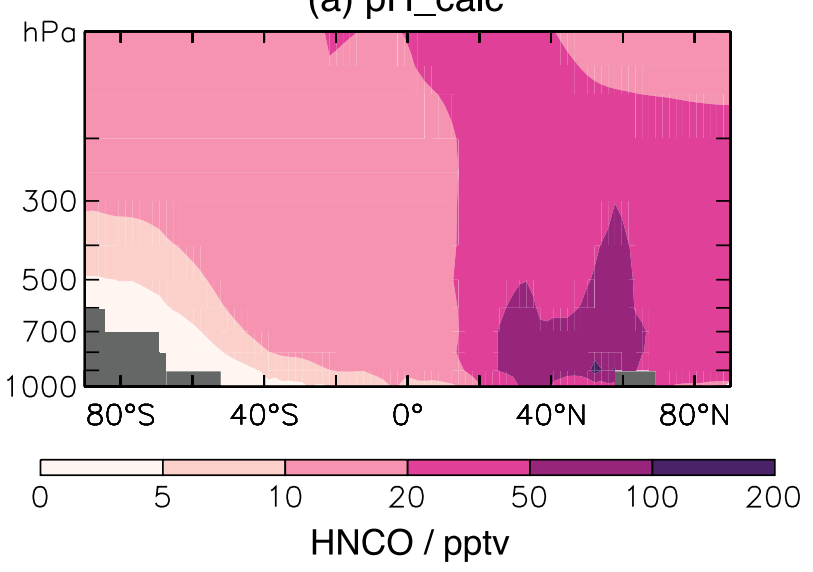

(b) 2xAnthro - pH_calc

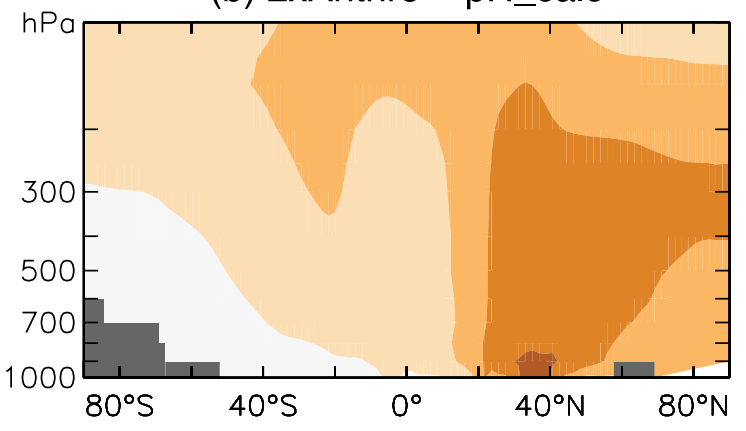

(c) $\mathrm{pH} 6-\mathrm{pH} \_$calc

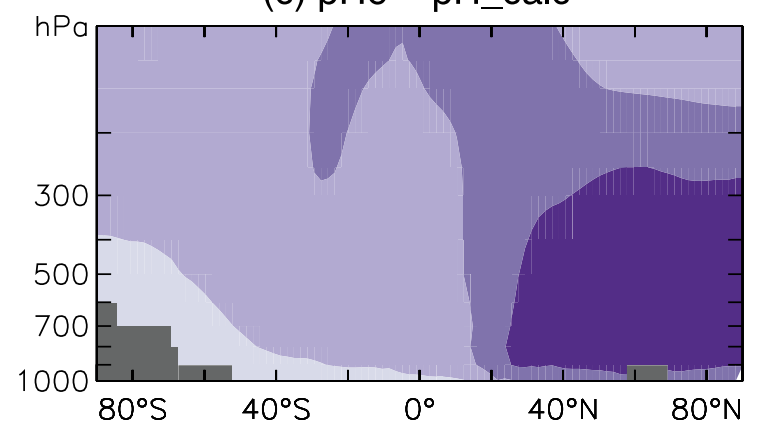

(d) $\mathrm{pH}$ - pH_calc

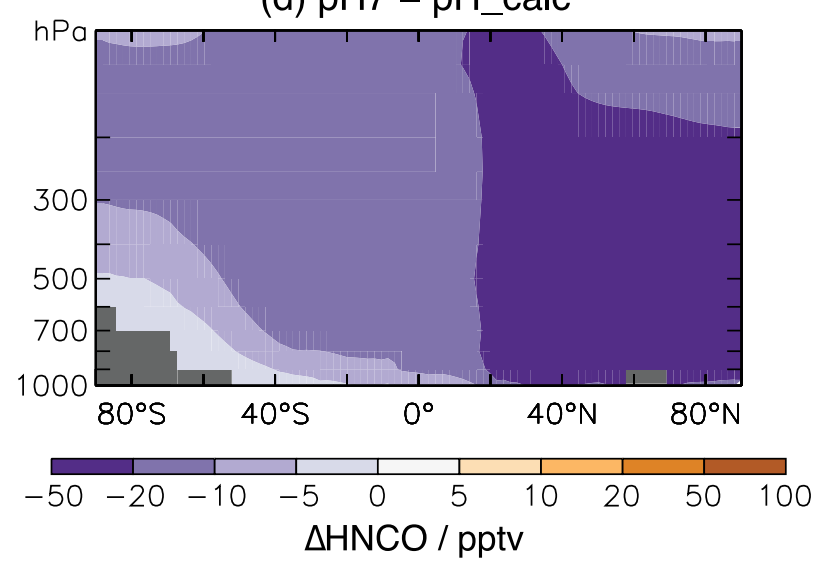

Figure 5. Same as Figure 4, but for annual mean, zonal mean HNCO. 


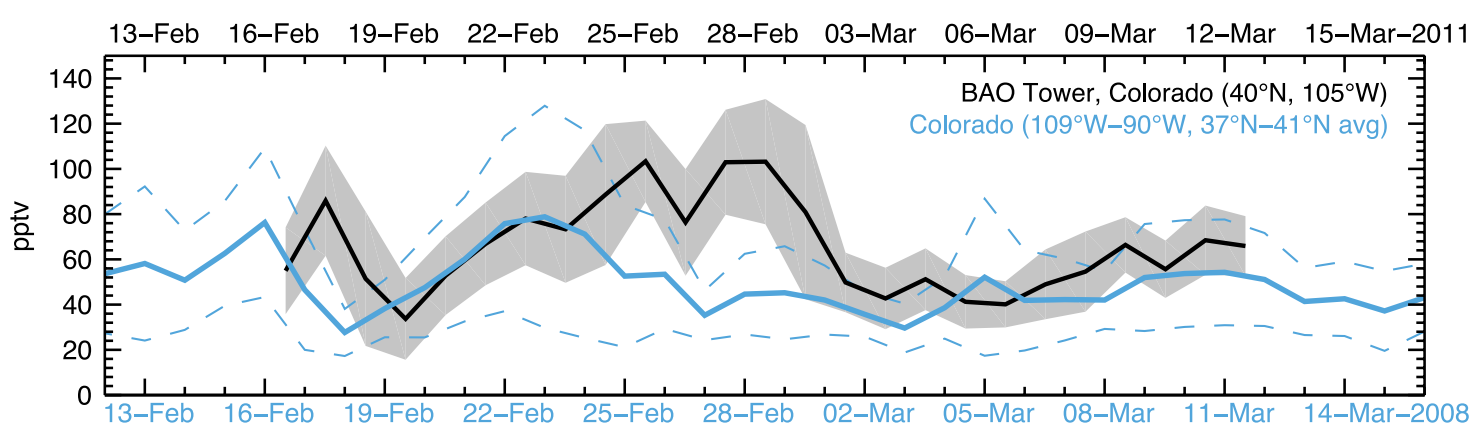

Figure 6. Comparison of simulated ( $\mathrm{pH}$ _calc) surface HNCO concentrations, averaged for Colorado, against HNCO observations made at the Boulder Atmospheric Observatory (BAO) Tower. BAO Tower observations were made in February and March 2011 (upper time axis), whereas the model data are appropriate for 2008 (lower time axis; note leap year). The blue dashed lines indicate $\pm 1 \sigma$ spatial variability for the model region. The shaded gray area indicates the $\pm 1 \sigma$ temporal variability for observations, as calculated from the $1 \mathrm{~min}$ data.

even in the monthly mean. This is discussed further in Section 5. Overall, Figure 4a suggests that "background" surface concentrations of HNCO are 0-20 pptv over the oceans and remote Southern Hemisphere (SH), and a few tens of pptv over landmasses.

[30] Figure 5a shows that the annual mean concentrations of HNCO decrease with altitude in the Northern Hemisphere $(\mathrm{NH})$, although the vertical gradient is small and midlatitude mean $\left(20^{\circ} \mathrm{N}-60^{\circ} \mathrm{N}\right)$ concentrations in the range $30-35$ pptv persist from $800 \mathrm{hPa}$ to $250 \mathrm{hPa}$. This appears to arise from appreciable vertical transport of surface emissions, coupled with a shift in the relative importance of the loss mechanisms. Above $\sim 400 \mathrm{hPa}$, the dominance of heterogeneous loss drops off rapidly (with drier conditions), and the slower chemical loss becomes the most important HNCO sink. It is likely that photolytic loss of HNCO would also be growing in importance with altitude, although, as stated in the introduction, assessing its importance depends on determining its absorption cross section.

[31] In contrast to the $\mathrm{NH}$, there is a reverse in the vertical gradient of $\mathrm{HNCO}$ concentration in the SH. Examination of vertical $\mathrm{HNCO}$ concentration profiles for different latitude bands (not shown) suggests that the middle and upper tropospheric annual mean enhancements are mainly from convection over regions with strong biomass burning (Africa and South America), followed by horizontal transport aloft to regions without notable HNCO emissions. There may also be a contribution from upper tropospheric, interhemispheric transport through the eastern Pacific [e.g., Staudt et al., 2001], although the horizontal distribution of HNCO concentrations around $300 \mathrm{hPa}$ suggests that this is small. In general, $\mathrm{HNCO}$ is relatively evenly distributed in longitude in the middle and upper troposphere, as the surface differences are smeared out by the strong westerlies.

[32] Figure 5a also shows that HNCO concentrations of 10-20 pptv persist in the tropical upper troposphere, and concentrations of $\sim 10$ pptv remain in the lower stratosphere $(70 \mathrm{hPa})$. As stated above, photolysis might be expected to account for an increasing fraction of the loss here and the model results should be interpreted with caution. Heterogeneous loss of HNCO in the tropics is reduced around $700 \mathrm{hPa}$, and above $400 \mathrm{hPa}$ due to reductions in cloud water content.
[33] Figure 6 compares the modeled ( $\mathrm{pH}$ _calc) surface HNCO concentrations, averaged for Colorado, against HNCO observations made during 2011 at the Boulder Atmospheric Observatory (BAO) Tower, in Erie, Colorado, USA $\left(40^{\circ} \mathrm{N}, 105^{\circ} \mathrm{W}\right)$. The modeled and observed concentrations are daily means, the latter calculated from $1 \mathrm{~min}$ data, with biomass burning plume data filtered out. There are several caveats when comparing the model against these observations (such as both representing different years, different emissions), which is why large-scale averages are used for the model data, in order to include different emission contributions. A comparison of the temporal means and the $1 \sigma$ variability (as computed from the data in Figure 6), suggests that the modeled $\mathrm{HNCO}$ concentrations are not unreasonable. The observed mean HNCO is $66 \pm 20$ pptv, compared to $49 \pm 13$ pptv for the model, although the model results are sensitive to the period chosen due to episodic emissions.

\subsubsection{Impact of Doubling Anthropogenic HNCO \\ Emissions}

[34] Figures $4 \mathrm{~b}$ and $5 \mathrm{~b}$ show the impact of doubling the anthropogenic emissions on the HNCO concentration. Figure $4 \mathrm{~b}$ looks much as expected, with increased annual mean surface $\mathrm{HNCO}$ concentrations over the regions with large anthropogenic emissions compared to the $\mathrm{pH}$ _calc simulation. This is especially the case for the Indo-Gangetic Plain and China, where grid cell increases are over 100 and 200 pptv, respectively. For China, this means that the annual mean surface HNCO concentration is $>900$ pptv. In relative terms, annual mean surface HNCO increases by more than $80 \%$ over the industrialized regions of Europe, parts of the Middle East, India, East Asia, and the eastern USA, but by less than $40 \%$ over tropical Africa and the Amazon, where biomass burning emissions dominate.

[35] Moving up in the troposphere, the differences between $\mathrm{pH}$ _calc and $2 \times$ Anthro are more uniform in longitude, with zonal mean differences dropping to $<50 \mathrm{pptv}$ above $700 \mathrm{hPa}$. Relative differences are reasonably constant, amounting to increases of 40 to $60 \%$ compared to $\mathrm{pH}$ _calc.

\subsubsection{Sensitivity of HNCO Distribution to $\mathbf{~ p H}$}

[36] Figures $4 \mathrm{c}$ and $4 \mathrm{~d}$ respectively show how increasing the $\mathrm{pH}$ to $\mathrm{pH}=6$ or 7 impacts the annual mean surface HNCO concentration. The largest absolute impacts of 
increasing the $\mathrm{pH}$ are found over China, although the peak annual mean concentration is still $450 \mathrm{pptv}$ for the $\mathrm{pH} 6$ simulation and $425 \mathrm{pptv}$ for the $\mathrm{pH} 7$ simulation. The largest relative impacts are over the remote oceanic regions, where less HNCO gets exported from the continental sources due to the faster loss rate at the higher $\mathrm{pHs}$. For the $\mathrm{pH} 7$ simulation, the increased loss is strong enough that the surface $\mathrm{HNCO}$ concentration in the remote ocean, and remote high latitudes is essentially zero. However, close to emission sources, increasing $\mathrm{pH}$ does not notably impact the surface concentration and distribution of HNCO.

[37] The same lack of $\mathrm{pH}$ sensitivity is not true of the vertical distribution of HNCO. Figures $5 \mathrm{c}$ and $5 \mathrm{~d}$ show the impact of increasing the $\mathrm{pH}$ on the zonal mean concentration of $\mathrm{HNCO}$. For the NH midlatitudes, annual zonal mean HNCO concentrations above $500 \mathrm{hPa}$ are in the 10-20 pptv range for $\mathrm{pH} 6$, and in the $5-10 \mathrm{pptv}$ range for $\mathrm{pH} 7$, representing decreases of $20-50 \mathrm{pptv}$ relative to $\mathrm{pH}$ _calc mean. For the pH6 simulation, export of $\mathrm{HNCO}$ to the remote $\mathrm{SH}$ upper troposphere is drastically reduced, with $40-70 \%$ decreases in HNCO concentrations between 500 and $250 \mathrm{hPa}$. For the $\mathrm{pH} 7$ simulation, the concentration of $\mathrm{HNCO}$ is extremely low in most locations ( $>70 \%$ decreases relative to $\mathrm{pH}$ _calc), with only the $\mathrm{NH}$ midlatitudes maintaining annual mean HNCO concentrations in excess of 5 pptv, although this is only below $300 \mathrm{hPa}$. As discussed in Section 2.1, distributing the biomass burning emissions vertically might also impact the vertical distribution of $\mathrm{HNCO}$, potentially increasing $\mathrm{HNCO}$ concentrations aloft and extending the tropospheric lifetime.

[38] Unlike for the $\mathrm{pH}$ _calc simulation, heterogeneous loss remains the dominant loss term for HNCO to above $300 \mathrm{hPa}$ with the $\mathrm{pH} 6$ and $\mathrm{pH} 7$ simulations, accounting for $>85 \%$ or $>95 \%$ of the total loss respectively. This dominance is unaffected by local minima in specific humidity, such as at $\sim 800-700 \mathrm{hPa}$ in the tropics, which serve to reduce the fraction of the total loss accounted for by heterogeneous processes in the $\mathrm{pH} \_$calc and other lower $\mathrm{pH}$ simulations.

[39] In summary, for the relatively high cloud liquid water $\mathrm{pHs}$, the $\mathrm{pH}$ is very important for determining the HNCO lifetime (and hence concentration and distribution) in the middle and upper troposphere, but it is less important for determining HNCO surface concentrations, which are more affected by the distribution of emissions. Comparing $\mathrm{pHs}$ in the range $3-5$, the impacts on $\mathrm{HNCO}$ concentrations are generally small at the surface and aloft. However, these results come with the caveat that aqueous-phase loss is assumed to be irreversible, and at higher $\mathrm{pHs} \mathrm{HNCO}$ would be expected to return to the gas phase.

\section{Surface HNCO Concentrations Exceeding 1 ppbv}

[40] Roberts et al. [2011] calculated that, based on a physiological $\mathrm{pH}$ of 7.4 , exposure to atmospheric $\mathrm{HNCO}$ concentrations exceeding $1 \mathrm{ppbv}$ could lead to sufficient in vivo concentrations of the cyanate anion $\left(\mathrm{NCO}^{-}\right)$to mimic the protein carbamylation chemistry seen with in vitro studies [Wang et al., 2007]. Based on this calculation, the modeled daily mean concentrations were analyzed to identify both how often and where surface HNCO concentrations are greater than, or equal to, 1 ppbv. In this section, concentrations of $\mathrm{HNCO}$ at or above this level are referred to as "elevated."

\subsection{Which Regions Are the Most Impacted?}

[41] Figures 7a-7c show the number of days in a yearlong simulation where the daily mean surface HNCO concentration of a particular model grid cell is elevated, for the pH_calc, $2 \times$ Anthro and $\mathrm{pH} 7$ simulations respectively. The gray boxes in Figure $7 \mathrm{c}$ highlight particular regions, which are defined in Table 2, and discussed further in the analysis below.

[42] Comparing Figure 7 with the distribution of HNCO emissions in Figure 1, it can be seen that the locations with elevated HNCO concentrations are largely those with notable biomass burning emissions (peak emissions $>5 \mathrm{Gg}$ HNCO (grid cell) ${ }^{-1} \mathrm{a}^{-1}$ ). These regions include those with recurrent seasonal biomass burning, such as tropical Africa, SE Asia and the Amazon [e.g., Bowman et al., 2009], as well as those regions with particularly large fires in 2008, such as Siberia [e.g., Warnecke et al., 2009]. For these regions, the number of days with elevated HNCO concentrations is almost the same in each of the simulations shown, underlining the small sensitivity of surface $\mathrm{HNCO}$ to changing $\mathrm{pH}$ shown in Section 4.2.2, and the fact that biomass burning emissions are causing the majority of the exceedences (i.e., that the $2 \times$ Anthro simulation has similar results to the others for these regions).

[43] Figure 8 further illustrates the importance of biomass burning for surface $\mathrm{HNCO}$ in some of the key regions defined in Table 2 (and as highlighted in Figure 7c). This figure shows the time series of daily total $\mathrm{HNCO}$ emissions (black; integrated over the given region), together with the time series of the regional maximum surface HNCO concentration (red), and the area-weighted regional mean surface HNCO concentration (blue). The red and blue curves show the spread for the $\mathrm{pH} 2$ to $\mathrm{pH} 7$ and $\mathrm{pH}$ _calc simulations, although the impact of $\mathrm{pH}$ is generally small. All three axes are the same scale in each panel.

[44] The correlation of high surface HNCO concentrations (maximum and average) with spikes in the emission field is clear for each region. The occurrence of particularly large $\mathrm{HNCO}$ emissions in SE Asia (Figure 8b) during March and April, and in Siberia (Figure 8c) from April to August, result in excursions of surface HNCO concentrations above 10 ppbv (several times in the case of Siberia). Regional average concentrations are also elevated for these regions with large emissions, and are close to $1 \mathrm{ppbv}$ for the biggest emission spikes.

[45] The mean total number of days (as calculated from all simulations) where the regional maximum surface $\mathrm{HNCO}$ concentration is $\geq 1 \mathrm{ppbv}$ is similar between SE Asia (55 days) and western Amazon (56 days), but is notably larger for Siberia (97 days) and tropical Africa (71 days), especially as the latter includes two separate biomass burning seasons either side of the equator ( January to March, and $\sim$ June to September). Instances of elevated HNCO concentrations in Canada exhibit the largest sensitivity to $\mathrm{pH}$, ranging from 30 to 43 days, mainly due to HCNO levels that are close to the $1 \mathrm{ppbv}$ threshold. The sensitivity is also related to the relatively high LWC in this region, meaning 
(a) $\mathrm{pH} \_$calc

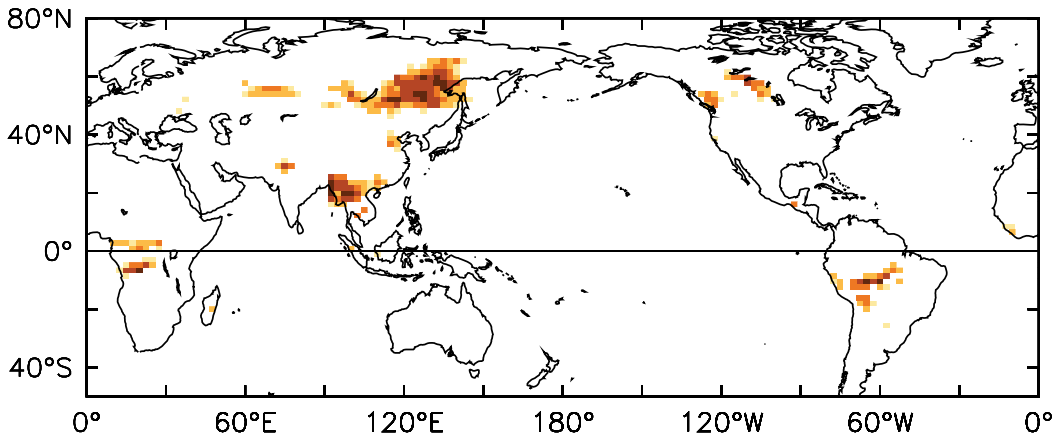

(b) 2xAnthro

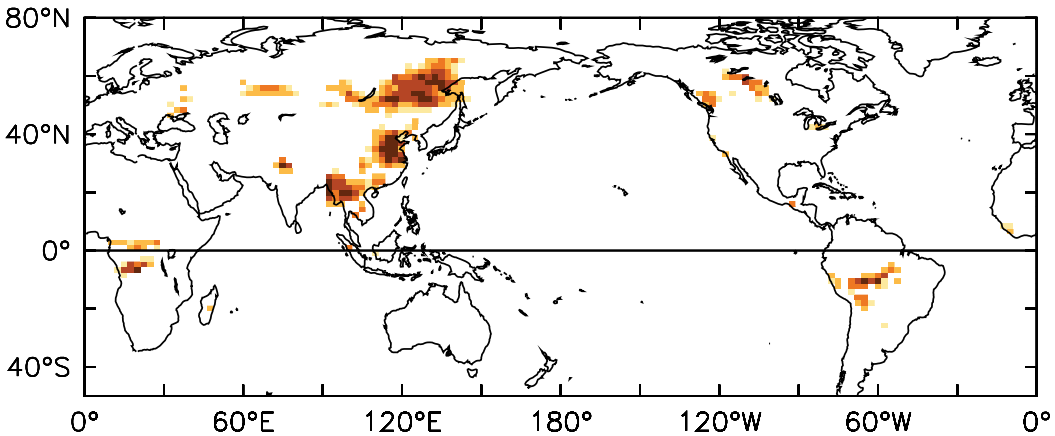

(c) $\mathrm{pH} 7$

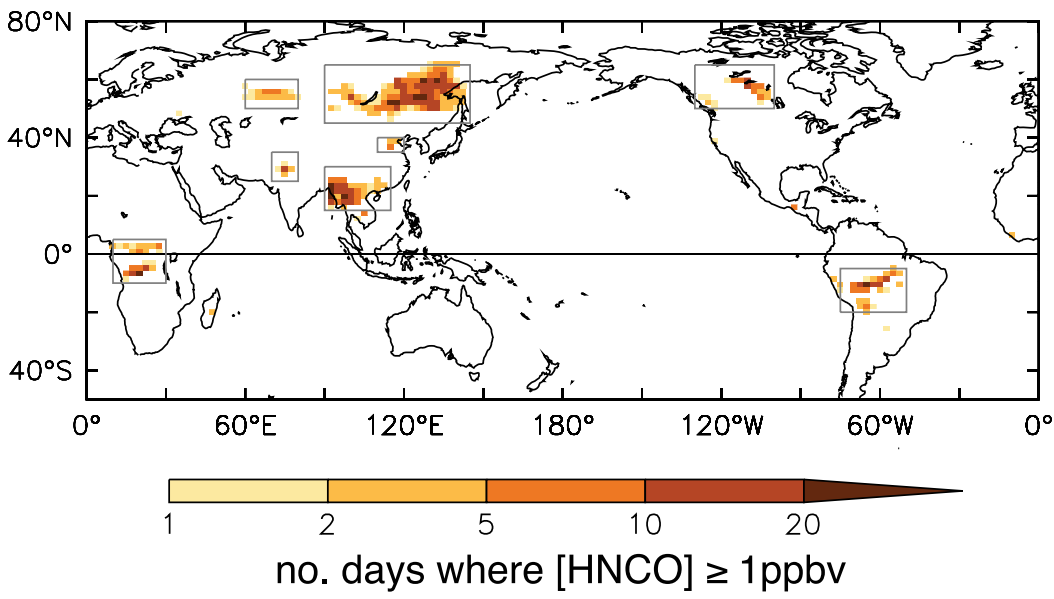

Figure 7. Number of days when a given grid cell surface HNCO concentration is $\geq 1$ ppbv during the model year, for the (a) pH_calc, (b) $2 \times$ Anthro, and (c) pH7 simulations. The boxes in Figure $7 \mathrm{c}$ highlight particular regions, defined in Table 2 and further analyzed in Figures 8-10.

that the impact of changing $\mathrm{pH}$ on the aqueous fraction is enhanced, compared to lower LWC regions (equation (2)).

[46] The occurrence of high HNCO concentrations in China is the exception to the biomass burning rule, since its $\mathrm{HNCO}$ emissions are almost all anthropogenic in origin. This is clearly seen by comparing this region in the $2 \times$ Anthro results (Figure $7 \mathrm{~b}$ ) against the other simulations (Figures $7 \mathrm{a}$ and $7 \mathrm{c}$ ). Figure $7 \mathrm{~b}$ also shows that the area of China where surface HNCO concentrations are elevated is expanded compared to the definition of "eastern China" in Table 2.

[47] Figure 9 shows a time series plot of the regional total emission, and maximum and average surface $\mathrm{HNCO}$
Table 2. Latitude/Longitude Bounds of the Regions Shown in Figures $7-10$

\begin{tabular}{lllll}
\hline \multicolumn{1}{c}{ Region } & Lon $\mathrm{W}$ & Lon $\mathrm{E}$ & Lat $\mathrm{S}$ & Lat $\mathrm{N}$ \\
\hline Tropical Africa & $10^{\circ} \mathrm{E}$ & $30^{\circ} \mathrm{E}$ & $10^{\circ} \mathrm{S}$ & $5^{\circ} \mathrm{N}$ \\
Urals & $60^{\circ} \mathrm{E}$ & $80^{\circ} \mathrm{E}$ & $50^{\circ} \mathrm{N}$ & $60^{\circ} \mathrm{N}$ \\
Northern India & $70^{\circ} \mathrm{E}$ & $80^{\circ} \mathrm{E}$ & $25^{\circ} \mathrm{N}$ & $35^{\circ} \mathrm{N}$ \\
Southeast Asia & $90^{\circ} \mathrm{E}$ & $115^{\circ} \mathrm{E}$ & $15^{\circ} \mathrm{N}$ & $30^{\circ} \mathrm{N}$ \\
Siberia & $90^{\circ} \mathrm{E}$ & $145^{\circ} \mathrm{E}$ & $45^{\circ} \mathrm{N}$ & $65^{\circ} \mathrm{N}$ \\
Eastern China & $110^{\circ} \mathrm{E}$ & $120^{\circ} \mathrm{E}$ & $35^{\circ} \mathrm{N}$ & $40^{\circ} \mathrm{N}$ \\
Canada & $130^{\circ} \mathrm{W}$ & $100^{\circ} \mathrm{W}$ & $50^{\circ} \mathrm{N}$ & $65^{\circ} \mathrm{N}$ \\
Western Amazon & $75^{\circ} \mathrm{W}$ & $50^{\circ} \mathrm{W}$ & $20^{\circ} \mathrm{S}$ & $5^{\circ} \mathrm{S}$ \\
\hline
\end{tabular}




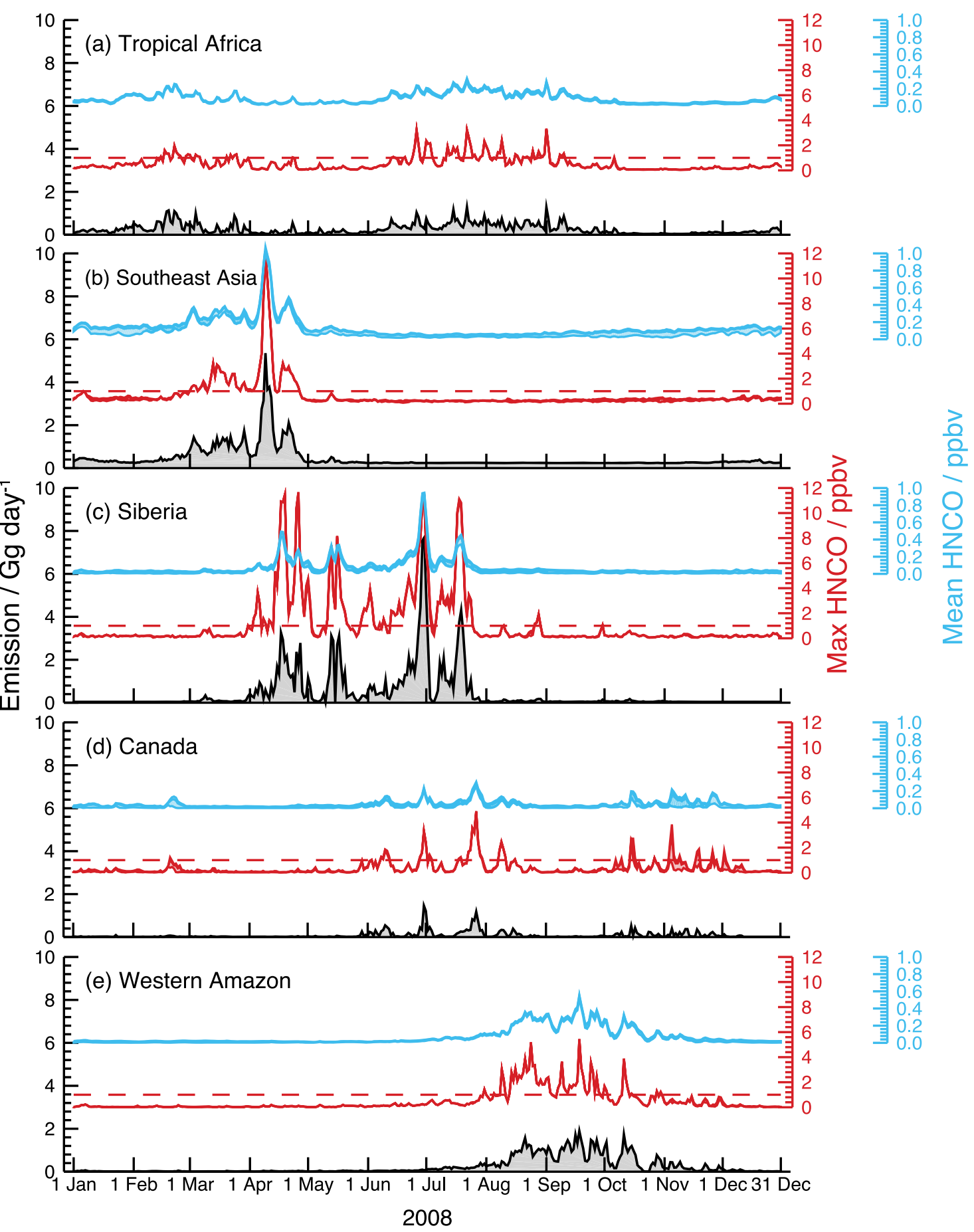

Figure 8. Time series of daily values of regional total HNCO emissions (left hand axis; black), regional maximum surface $\mathrm{HNCO}$ concentrations (1st right hand axis; red), and area-weighted regional mean surface HNCO concentrations (2nd right hand axis; blue). The maximum and mean HNCO data consist of two lines (not always visible) with shading in-between, indicating the range of data from the $\mathrm{pH} 2-\mathrm{pH} 7$ and $\mathrm{pH}$ _calc simulations. The red dashed line indicates $1 \mathrm{ppbv}$ for the maximum surface HNCO axis. Regions shown are (a) tropical Africa, (b) SE Asia, (c) Siberia, (d) Canada, and (e) western Amazon. Regions are defined in Table 2.

concentration for eastern China. Figure 9a shows the time series for the $\mathrm{pH} 2-\mathrm{pH} 7$ and $\mathrm{pH}$ _calc simulations (as per Figure 8 ), and Figure $9 \mathrm{~b}$ shows the time series for $2 \times$ Anthro simulation. For the $2 \times$ Anthro simulation, the regional maximum surface $\mathrm{HNCO}$ concentration is elevated for
175 days, compared to a range of 7-10 days for all the other simulations. This is perhaps not too surprising, since, based on the emissions factors used in this study, the $2 \times$ Anthro daily $\mathrm{HNCO}$ emissions in this region approach the smaller biomass burning emissions seen in the other regions. 


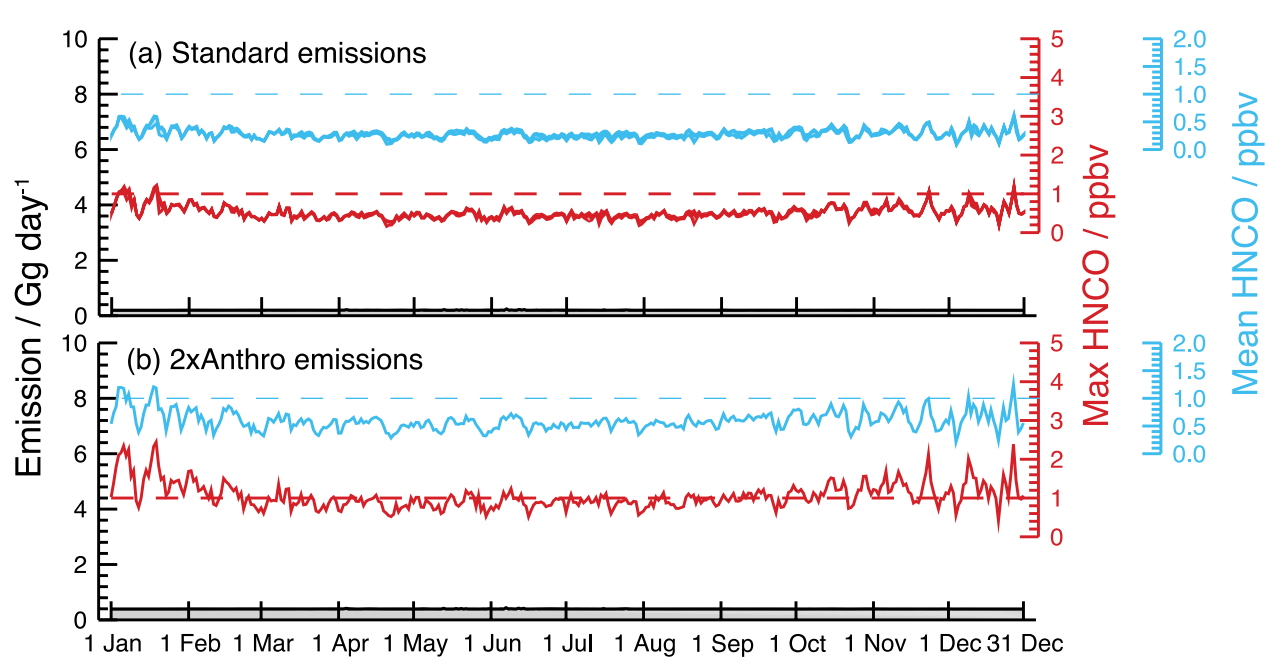

Figure 9. Time series of daily values of regional total HNCO emissions, regional maximum surface $\mathrm{HNCO}$, and area-weighted regional mean surface $\mathrm{HNCO}$ in the style of Figure 8, but for eastern China. (a) Results from the $\mathrm{pH} 2-\mathrm{pH} 7$ and $\mathrm{pH}$ calc simulations and (b) results from the $2 \times$ Anthro simulations. Note that the red and blue axes have different ranges compared to Figure 8.

Figure 8 shows that daily emissions of $\mathrm{HNCO}$ over $\sim 0.5 \mathrm{Gg}$ often result in regional maximum concentrations exceeding 1 ppbv.

\subsection{Population-Weighted Impact}

[48] Figure 10 presents a different perspective on comparing the regions. Figure 10a shows the number of days where the regional maximum surface HNCO concentration is elevated as mentioned above, but including all the regions in Table 2. The data are from the $\mathrm{pH} 7$ simulation (i.e., representing the lower bound for the number of days), although differences with the other $\mathrm{pH}$ simulations are small or non-existent (0-3 days). The Urals, northern India, and

(a) Days where regional max $\mathrm{HNCO} \geq 1 \mathrm{ppbv}$

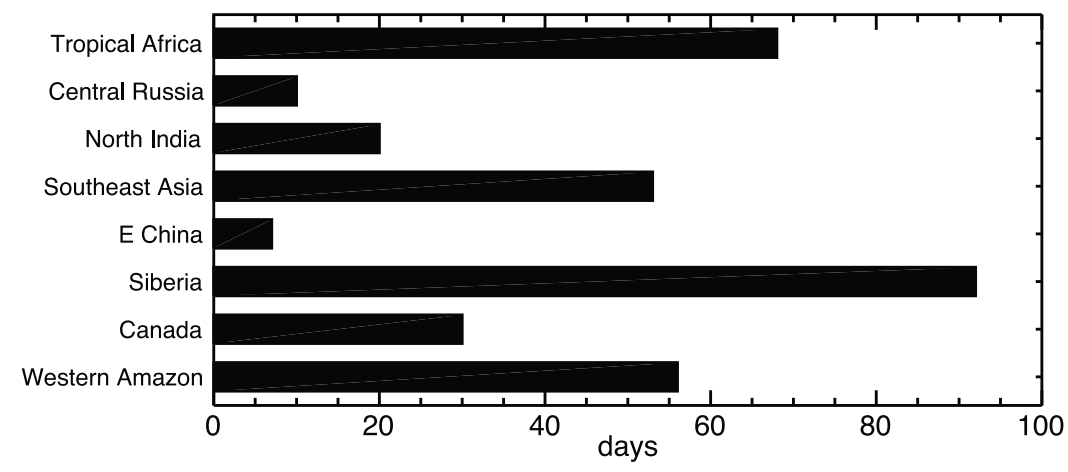

(b) Exposure to $\mathrm{HNCO} \geq 1$ ppbv for $\geq 7$ days per year

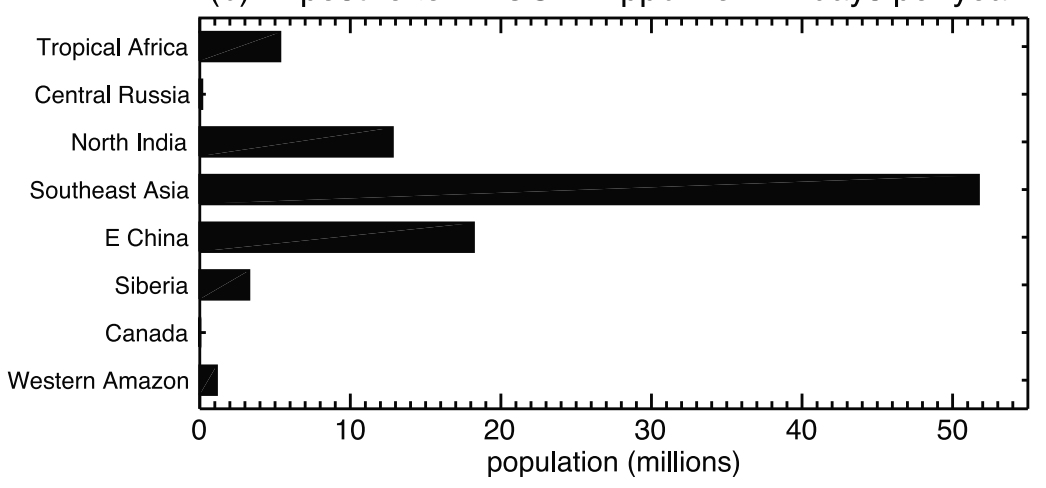

Figure 10. (a) Number of days where the regional maximum surface HNCO concentration is $\geq 1$ ppbv by region. (b) Population exposed to surface HNCO concentrations $\geq 1$ ppbv for at least 7 days, by region. Results are from the $\mathrm{pH} 7$ simulation. Regions are as defined in Table 2. 
Table 3. Globally Integrated Number of Days When the Surface Concentration of HNCO Exceeds a Given Threshold, for the pH_calc, pH6, pH7 and $2 \times$ Anthro Simulations ${ }^{\mathrm{a}}$

\begin{tabular}{lccccc}
\hline & \multicolumn{5}{c}{ Threshold Surface HNCO Concentration } \\
\cline { 2 - 6 } & 500 pptv & 750 pptv & 1 ppbv & 2 ppbv & 5 ppbv \\
\hline pH_calc & 6435 & 3084 & 1894 & 599 & 110 \\
pH6 & 5708 & 2852 & 1792 & 581 & 107 \\
pH7 & 4937 & 2589 & 1647 & 546 & 100 \\
2xAnthro & 16607 & 6403 & 2983 & 643 & 110 \\
\hline
\end{tabular}

${ }^{\mathrm{a}}$ Number of days calculated for each individual grid cell and then summed.

eastern China have the lowest number of days of high HNCO concentrations, with Siberia clearly having the largest. However, as elevated HNCO concentrations are potentially a human health issue, Figure $10 \mathrm{~b}$ expresses the regional differences in terms of the population exposed to elevated $\mathrm{HNCO}$ concentrations for (cumulatively) 7 days or more (an arbitrary threshold), again using data from the $\mathrm{pH} 7$ simulation. These populations were calculated on a grid cell basis, by determining the grid cells where elevated surface HNCO concentrations occurred for $\geq 7$ days and using gridded population density data from Center for International Earth Science Information Network et al. [2005] (scaled to give a global population of 6.025 billion, from the year 2000 United Nations estimate). Many of the regions with high numbers of days when the HNCO concentration is elevated (tropical Africa, Siberia, Canada and western Amazon) are also the least populated, whereas eastern China and northern India have fewer days of exceedences but large populations. SE Asia is doubly impacted, with a high population and many days with high HNCO concentrations.

\subsection{Impact of Changing the Threshold Concentration}

[49] On one hand, using daily average concentrations, taking the lower $\mathrm{HNCO} / \mathrm{HCN}$ emission ratio, and assuming irreversible uptake for heterogeneous loss means that this analysis could underestimate the occurrences of elevated HNCO. On the other hand, the lack of vertically distributed fire emissions means that these occurrences could be overestimated. To somewhat address this, Table 3 shows the globally integrated number of days where the surface $\mathrm{HNCO}$ concentration exceeds different thresholds (ranging from 500 pptv to 5 ppbv), calculated on a per grid cell basis - i.e., the number of days a given grid cell exceeds the threshold concentration in a year is determined, and then all the grid cells are summed together. Data are shown for the $\mathrm{pH}$ _calc, $\mathrm{pH} 6, \mathrm{pH} 7$ and 2xAnthro simulations.

[50] Using a higher HNCO concentration threshold clearly reduces the number of days of exceedences, but there is generally close agreement between the " $\mathrm{pH}$ " simulations (including those not shown in Table 3), as is also illustrated by the similarity of Figures $7 \mathrm{a}$ and $7 \mathrm{c}$. The results from the $2 \times$ Anthro simulation show large differences compared to the other simulations for threshold $\mathrm{HNCO}$ concentrations up to $1 \mathrm{ppbv}$, but are more similar when the threshold is $2 \mathrm{ppbv}$ or $5 \mathrm{ppbv}$. This demonstrates that the large spikes in biomass burning (Figure 8) drive the very large $\mathrm{HNCO}$ concentrations.

[51] To summarize Section 5, the regions that have the largest number of occurrences of elevated surface $\mathrm{HNCO}$ concentrations are generally those that have large biomass burning emissions, and the HNCO concentrations exceed $1 \mathrm{ppbv}$ at the time of the emission. The exception is for locations with very large anthropogenic emissions, typified by China in this study. In this region, maximum surface $\mathrm{HNCO}$ concentrations are generally close to $1 \mathrm{ppbv}$ yearround with the standard emissions, and doubling the anthropogenic emissions means that these maximum concentrations are $\geq 1 \mathrm{ppbv}$ for almost half the year.

\section{Discussion}

[52] The results presented in Sections 4 and 5 suggest that elevated $(\geq 1 \mathrm{ppbv})$ surface $\mathrm{HNCO}$ concentrations are probable, particularly in regions impacted by biomass burning, or with very large anthropogenic emissions. If these results were to be borne out by observations, this would mean that many millions of people are exposed to levels of HNCO that could be high enough to damage their health, although HNCO levels are not controlled by any government. However, there remain several uncertainties and knowledge gaps, both related to this study and to understanding of the connection between HNCO exposure and resulting health effects.

[53] This study suggests that surface HNCO emissions are likely the most important factor in determining where and when surface HNCO concentrations are elevated. Emissions also remain one of the most uncertain factors in this work, being a highly derived quantity from HCN (and CO) emissions, coupled with the general uncertainty in estimates of anthropogenic [e.g., Lamarque et al., 2010; Verma et al., 2011] and biomass burning [e.g., Wiedinmyer et al., 2011] emissions, including their vertical distribution. Besides the confirmed measurements of HNCO from fires, other sources of HNCO are not generally well understood. Preliminary analysis of observational data from a field campaign in California and the USA Pacific coastal region (CalNex; http://www.esrl.noaa.gov/csd/calnex/) suggests that both primary and secondary (i.e., photochemical) sources of $\mathrm{HNCO}$ are important for the Los Angeles region, which, based on the characteristics of that region, could suggest a contributing automotive source not fully accounted for here.

[54] In addition, full accounting of the distribution and source strength of $\mathrm{HNCO}$ from biofuel emissions was not done in this study, as the anthropogenic emissions were scaled from total (fossil fuel and biofuel) $\mathrm{CO}$ emissions. Furthermore, estimates of biofuel emissions from domestic cooking (of all species) are very uncertain [Rehman et al., 2011]. Understanding this source of HNCO should be a priority not only for better characterizing regional emissions, but mainly because of the potential health impacts of high HNCO exposure through indoor fires, which add to the other known health effects from this source [Ezzati and Kammen, 2002].

[55] By scaling $\mathrm{HCN}$ emissions by 0.3 , this study used the lower bound of $\mathrm{HNCO} / \mathrm{HCN}$ ratio measured by Roberts et al. [2011] to determine the HNCO emissions. It is expected that increasing this scale factor to 0.5 (the upper bound) would increase the peak surface $\mathrm{HNCO}$ concentrations in the major biomass burning emitting regions shown in Figure 8 . Moreover, increasing the scale factor could increase the number of days of elevated $\mathrm{HNCO}$ concentrations in 
regions with more moderate biomass burning emissions, such as northern India, the Urals and parts of Central America (see Figure 1a), thus greatly increasing the total population exposed to potentially deleterious HNCO concentrations.

[56] Of course, what constitutes "deleterious" concentrations of HNCO is also uncertain. Little is known about the exposure/response relationships of $\mathrm{HNCO}$, and it could be that chronic exposure to moderate levels of HNCO (e.g., $<1$ ppbv, but several 100 pptv) could have health impacts. Such chronic exposure would be an issue in areas with large anthropogenic emissions, as shown for the particular case of China in these results.

[57] Overall, this study suggests that areas impacted by either very large anthropogenic emissions, or large biomass burning emissions are likely to experience periods where surface HNCO concentrations greatly exceed 1 ppbv, irrespective of the environmental $\mathrm{pH}$. While the emissions may be uncertain, the fact that modeled HNCO concentrations are often $>4$ ppbv during the fire seasons suggests that the error (which could go either way) would have to be very large for there to be no areas with elevated HNCO concentrations. Based on the results here, there is now a need to increase the coverage of HNCO observational data, particularly in areas impacted by biomass burning, both for model validation and to determine whether there are large populations at a potential risk.

\section{Summary and Conclusions}

[58] This study used the chemical transport model MOZART-4 to make the first estimate of the tropospheric distribution and budget of isocyanic acid (HNCO), a toxin that has only recently been measured in the ambient atmosphere. The model included HNCO emissions from biomass burning (year 2008) and anthropogenic sources, and loss processes via wet and dry deposition (relatively fast), and reaction with $\mathrm{OH}$ (very slow).

[59] The results suggest that several regions, and large populations are exposed to surface concentrations of $\mathrm{HNCO} \geq 1$ ppbv, which is the level at which deleterious health effects might be expected. For surface HNCO concentrations, the magnitude of the local emission is the key factor in determining their level. Regions that experienced large fire emissions (tropical Africa, SE Asia, Siberia, Canada and the Amazon) had the highest surface concentrations of HNCO, generally far higher than 1 ppbv on several days. While Siberia had the highest concentrations of $\mathrm{HNCO}$ and the greatest number of days where HNCO was greater than $1 \mathrm{ppbv}, \mathrm{SE}$ Asia is far more populated, and was the region with the greatest number of people exposed to the elevated HNCO. Surface HNCO levels over China were also high, due to large anthropogenic emissions. In the standard simulation, maximum surface $\mathrm{HNCO}$ concentrations over China were close to $1 \mathrm{ppbv}$, exceeding that level for 9 days. However, in a simulation with doubled anthropogenic emissions, this increased to 173 days. Other regions generally have far less anthropogenic emissions, so the impact of doubling them did not push the HNCO concentrations above 1 ppbv.

[60] Tropospheric budget statistics of HNCO demonstrate the importance of cloud water $\mathrm{pH}$, which controls the fraction of the total loss via wet deposition. While a small term in the total budget, loss of $\mathrm{HNCO}$ via reaction with $\mathrm{OH}$ becomes more important at higher altitudes (above $400 \mathrm{hPa}$ ), where it is also possible that photolytic loss could be a key budget term. Both the burden and lifetime decrease markedly when the $\mathrm{pH}$ is fixed globally at a relatively high value ( $\mathrm{pH} 5-7)$, compared to more acidic simulations ( $\mathrm{pH} 2-4)$ and when using the model-calculated $\mathrm{pH}$, as the heterogeneous loss increases in importance and dominates over dry deposition. Acidity is of great importance for transport of $\mathrm{HNCO}$ to remote areas and its distribution in the middle and upper troposphere, and export of $\mathrm{HNCO}$ from emitting regions to these parts of the atmosphere is greatly reduced in the $\mathrm{pH} 6$ and $\mathrm{pH} 7$ simulations. The model-calculated $\mathrm{pH}$ is likely too acidic, likely mainly due to the absence of the basic influence of soil dust (from $\mathrm{Ca}^{2+}$ ). Furthermore, the assumption that the heterogeneous loss is irreversible likely means that this loss process is over-estimated here. However, over land, surface concentrations of HNCO were mostly insensitive to changes in $\mathrm{pH}$, suggesting that HNCO emissions are the key area to validate and improve on.

[61] While this study was completed with a model that has some limitations, and an uncertain understanding of $\mathrm{HNCO}$ emissions and loss processes, it has identified that regions with very large anthropogenic emissions and those impacted by biomass burning have populations potentially at risk of being exposed to elevated HNCO concentrations. More HNCO observations are needed in these parts of the world to validate the model, and help improve emissions estimates, particularly from biofuel use. Furthermore, a better understanding on what concentrations of HNCO lead to deleterious health effects would aid a more comprehensive risk assessment for this compound.

[62] Acknowledgments. We thank John Orlando for helpful comments on the manuscript and throughout the study, as well as the reviewers for their constructive comments. We acknowledge the use of the Boulder Atmospheric Observatory (BAO), and Daniel Wolfe and Bruce Bartram of the NOAA/ESRL Physical Sciences Division, and William Dubé and Nicholas Wagner of NOAA/ESRL Chemical Sciences Division and CIRES, for their excellent help in conducting the measurements at the BAO. This work was supported in part by the NOAA Atmospheric Chemistry and Climate, and Health of the Atmosphere Programs. The National Center for Atmospheric Research is operated by the University Corporation for Atmospheric Research under sponsorship of the National Science Foundation.

\section{References}

Barnes, I., G. Solignac, A. Mellouki, and K. H. Becker (2010), Aspects of the atmospheric chemistry of amides, Eur. J. Chem. Phys. Phys. Chem., 11(18), 3844-3857, doi:10.1002/cphc.201000374.

Belson, D. J., and A. N. Strachan (1982), Preparation and properties of isocyanic acid, Chem. Soc. Rev., 11(1), 41-56, doi:10.1039/cs9821100041.

Berghout, H. L., S. S. Brown, R. Delgado, and F. Fleming Crim (1998), Nonadiabatic effects in the photodissociation of vibrationally excited HNCO: The branching between singlet $\left(a^{1} \Delta\right)$ and triplet $\left(X^{3} \Sigma^{-}\right) \mathrm{NH}$, J. Chem. Phys., 109(6), 2257-2263, doi:10.1063/1.476793.

Bowman, D., et al. (2009), Fire in the Earth system, Science, 324(5926), 481-484, doi:10.1126/science.1163886.

Brown, S. S., H. L. Berghout, and F. F. Crim (1996), The HNCO heat of formation and the $\mathrm{N}-\mathrm{H}$ and $\mathrm{C}-\mathrm{N}$ bond enthalpies from initial state selected photodissociation, J. Chem. Phys., 105(18), 8103-8110, doi:10.1063/1.472664.

Brownsword, R. A., T. Laurent, R. K. Vatsa, H. R. Volpp, and J. Wolfrum (1996), Photodissociation dynamics of HNCO at $248 \mathrm{~nm}$, Chem. Phys. Lett., 258(1-2), 164-170, doi:10.1016/0009-2614(96)00626-4.

Burling, I. R., et al. (2010), Laboratory measurements of trace gas emissions from biomass burning of fuel types from the southeastern and southwestern United States, Atmos. Chem. Phys., 10(22), 11,115-11,130, doi:10.5194/acp-10-11115-2010. 
Center for International Earth Science Information Network, Columbia University, and Centro Internacional de Agricultura Tropical (2005), Gridded Population of the World, version 3 (GPWv3), 2011-10-03, http://sedac.ciesin.columbia.edu/gpw, Socioeconomic Data and Appl. Cent., Palisades, N. Y.

Crutzen, P. J., and M. O. Andreae (1990), Biomass burning in the tropics: Impact on atmospheric chemistry and biogeochemical cycles, Science, 250(4988), 1669-1678, doi:10.1126/science.250.4988.1669.

Dixon, R. N., and G. H. Kirby (1968), Ultra-violet absorption spectrum of isocyanic acid, Trans. Faraday Soc., 64, 2002-2012, doi:10.1039/ tf9686402002.

Emmons, L. K., et al. (2010), Description and evaluation of the Model for Ozone and Related chemical Tracers, version 4(MOZART-4), Geosci. Model Dev., 3(1), 43-67, doi:10.5194/gmd-3-43-2010.

Ezzati, M., and D. M. Kammen (2002), The health impacts of exposure to indoor air pollution from solid fuels in developing countries: Knowledge, gaps, and data needs, Environ. Health Perspect., 110(11), 1057-1068.

Fromm, M., R. Bevilacqua, R. Servranckx, J. Rosen, J. P. Thayer, J. Herman, and D. Larko (2005), Pyro-cumulonimbus injection of smoke to the stratosphere: Observations and impact of a super blowup in northwestern Canada on 3-4 August 1998, J. Geophys. Res., 110, D08205, doi:10.1029/2004JD005350.

Heeb, N. V., et al. (2011), Reactive nitrogen compounds (RNCs) in exhaust of advanced PM-NOx abatement technologies for future diesel applications, Atmos. Environ., 45(18), 3203-3209, doi:10.1016/j.atmosenv. 2011.02.013.

Jacob, D. J. (2000), Heterogeneous chemistry and tropospheric ozone, Atmos. Environ., 34(12-14), 2131-2159, doi:10.1016/S1352-2310(99) 00462-8.

Keene, W. C., and J. N. Galloway (1988), The biogeochemical cycling of formic and acetic acids through the troposphere: An overview of current understanding, Tellus, Ser. B, 40(5), 322-334, doi:10.1111/j.1600-0889. 1988.tb00106.x.

Kröcher, O., M. Elsener, and M. Koebel (2005), An ammonia and isocyanic acid measuring method for soot containing exhaust gases, Anal. Chim. Acta, 537(1-2), 393-400, doi:10.1016/j.aca.2004.12.082.

Lamarque, J.-F., et al. (2010), Historical (1850-2000) gridded anthropogenic and biomass burning emissions of reactive gases and aerosols: Methodology and application, Atmos. Chem. Phys., 10, 7017-7039, doi:10.5194/acp-10-7017-2010.

Li, Z., and V. P. Aneja (1992), Regional analysis of cloud chemistry at high elevations in the eastern United States, Atmos. Environ., Part A, 26(11), 2001-2017, doi:10.1016/0960-1686(92)90085-Y.

Nelson, P. F., C.-Z. Li, and E. Ledesma (1996), Formation of HNCO from the rapid pyrolysis of coals, Energy Fuels, 10(1), 264-265, doi:10.1021/ ef950183o.

Pfister, G., P. G. Hess, L. K. Emmons, J.-F. Lamarque, C. Wiedinmyer, D. P. Edwards, G. Pétron, J. C. Gille, and G. W. Sachse (2005), Quantifying CO emissions from the 2004 Alaskan wildfires using MOPITT CO data, Geophys. Res. Lett., 32, L11809, doi:10.1029/2005GL022995.

Randel, W., M. Park, L. Emmons, D. Kinnison, P. Bernath, K. Walker, C. Boone, and H. Pumphrey (2010), Asian monsoon transport of pollution to the stratosphere, Science, 328(5978), 611-613, doi:10.1126/ science. 1182274.

Rehman, I. H., T. Ahmed, P. S. Praveen, A. Kar, and V. Ramanathan (2011), Black carbon emissions from biomass and fossil fuels in rural India, Atmos. Chem. Phys., 11(14), 7289-7299, doi:10.5194/acp-117289-2011.
Roberts, J. M., et al. (2010), Measurement of HONO, HNCO, and other inorganic acids by negative-ion proton-transfer chemical-ionization mass spectrometry (NI-PT-CIMS): Application to biomass burning emissions, Atmos. Meas. Tech., 3(4), 981-990, doi:10.5194/amt-3-981-2010.

Roberts, J. M., et al. (2011), Isocyanic acid in the atmosphere and its possible link to smoke-related health effects, Proc. Natl. Acad. Sci. U. S. A., 108(22), 8966-8971, doi:10.1073/pnas.1103352108.

Rodhe, H., F. Dentener, and M. Schulz (2002), The global distribution of acidifying wet deposition, Environ. Sci. Technol., 36(20), 4382-4388, doi:10.1021/es020057g.

Schade, G. W., and P. J. Crutzen (1995), Emission of aliphatic amines from animal husbandry and their reactions: Potential source of $\mathrm{N}_{2} \mathrm{O}$ and $\mathrm{HCN}$, J. Atmos. Chem., 22(3), 319-346, doi:10.1007/BF00696641.

Staudt, A. C., D. J. Jacob, J. A. Logan, D. Bachiochi, T. N. Krishnamurti, and G. W. Sachse (2001), Continental sources, transoceanic transport, and interhemispheric exchange of carbon monoxide over the Pacific, J. Geophys. Res., 106(D23), 32,571-32,589, doi:10.1029/2001JD900078.

Stevenson, D. S., et al. (2006), Multimodel ensemble simulations of presentday and near-future tropospheric ozone, J. Geophys. Res., 111, D08301, doi:10.1029/2005JD006338.

Tsang, W. (1992), Chemical kinetic data base for propellant combustion. II. Reactions involving $\mathrm{CN}, \mathrm{NCO}$, and HNCO, J. Phys. Chem. Ref. Data, 21(4), 753-791, doi:10.1063/1.555914.

Veres, P., J. M. Roberts, C. Warneke, D. Welsh-Bon, M. Zahniser, S. Herndon, R. Fall, and J. A. de Gouw (2008), Development of negativeion proton-transfer chemical-ionization mass spectrometry (NI-PT-CIMS) for the measurement of gas-phase organic acids in the atmosphere, Int. J. Mass Spectrom., 274(1-3), 48-55, doi:10.1016/j.ijms.2008.04.032.

Veres, P., J. M. Roberts, I. R. Burling, C. Warneke, J. de Gouw, and R. J. Yokelson (2010), Measurements of gas-phase inorganic and organic acids from biomass fires by negative-ion proton-transfer chemical-ionization mass spectrometry, J. Geophys. Res., 115, D23302, doi:10.1029/ 2010JD014033.

Verma, R. L., Y. Kondo, N. Oshima, H. Matsui, K. Kita, L. K. Sahu, S. Kato, Y. Kajii, A. Takami, and T. Miyakawa (2011), Seasonal variations of the transport of black carbon and carbon monoxide from the Asian continent to the western Pacific in the boundary layer, J. Geophys. Res., 116, D21307, doi:10.1029/2011JD015830.

Wang, Z., S. J. Nicholls, E. R. Rodriguez, O. Kummu, S. Hörkkö, J. Barnard, W. F. Reynolds, E. J. Topol, J. A. DiDonato, and S. L. Hazen (2007), Protein carbamylation links inflammation, smoking, uremia and atherogenesis, Nat. Med., 13(10), 1176-1184, doi:10.1038/nm1637.

Warnecke, C., et al. (2009), Biomass burning in Siberia and Kazakhstan as an important source for haze over the Alaskan Arctic in April 2008, Geophys. Res. Lett., 36, L02813, doi:10.1029/2008GL036194.

Wespes, C., et al. (2012), Analysis of ozone and nitric acid in spring and summer Arctic pollution using aircraft, ground-based, satellite observations and MOZART-4 model: Source attribution and partitioning, Atmos. Chem. Phys., 12(1), 237-259, doi:10.5194/acp-12-237-2012.

Wiedinmyer, C., S. K. Akagi, R. J. Yokelson, L. K. Emmons, J. A. Al-Saadi, J. J. Orlando, and A. J. Soja (2011), The Fire Inventory from NCAR (FINN): A high resolution global model to estimate the emissions from open burning, Geosci. Model Dev., 4(3), 625-641, doi:10.5194/ gmd-4-625-2011.

Zhang, Q., et al. (2009), Asian emissions in 2006 for the NASA INTEX-B mission, Atmos. Chem. Phys., 9(14), 5131-5153, doi:10.5194/acp-95131-2009. 